\title{
Varieties of Capitalism and institutional comparative advantage: A test and reinterpretation
}

\author{
Michael A. Witt ${ }^{1}$ and \\ Gregory Jackson ${ }^{2}$ \\ ${ }^{1}$ INSEAD, 1 Ayer Rajah Avenue, \\ Singapore 138676, Singapore; ${ }^{2}$ Free University \\ of Berlin, Berlin, Germany
}

Correspondence:

Michael A. Witt, INSEAD, 1 Ayer Rajah Avenue, Singapore 138676, Singapore. Tel: +65-6799-5388;

Fax: +65-6799-5399;

e-mail: michael.witt@insead.edu

\begin{abstract}
How do national-level institutions relate to national comparative advantages? We seek to shed light on this question by exploring two different sets of hypotheses based on the Varieties of Capitalism and other branches of comparative capitalisms literature. Applying fuzzy-set qualitative comparative analysis to data from 14 industries in 22 countries across 9 years, we find that comparative advantages in industries with radical innovation emerge in specific configurations mixing coordinated and liberal institutional features. Institutional comparative advantage in industries with radical innovation may thus be based on the "beneficial constraints" of opposing institutional logics rather than on the self-reinforcing institutional coherence envisioned in much of the Varieties of Capitalism literature. By contrast, we find that coordinated market economies may have comparative advantages in industries with incremental innovation, as envisioned in the Varieties of Capitalism literature. Our article contributes to our understanding of the "so what?" related to capitalist diversity and its implications for location decisions of multinational enterprises. We further present a coordination index going beyond Hall and Gingerich (Br J Polit Sci 39:449-482, 2009) with annual values for 22 OECD countries from 1995 through 2003.

Journal of International Business Studies (2016) 47, 778-806. doi: 10.1057/s4 |267-016-0001-8
\end{abstract}

Keywords: Varieties of Capitalism; economic sociology; comparative advantage; institutional context; fuzzy-set methods

The online version of this article is available Open Access

\section{INTRODUCTION}

What explains national comparative advantages? Almost 200 years after the publication of David Ricardo's On the Principles of Political Economy and Taxation in 1817, the question has not conclusively been answered. Traditional economics explanations, including Ricardo's and the later Heckscher-Ohlin model of trade, have emphasized the importance of inherited natural endowments with production factors such as labor and land. Empirical performance of these models, however, is weak (Trefler \& Zhu, 2000).

More recent alternative explanations are based on the diverse institutional characteristics of national economies. ${ }^{1}$ Comparative studies have argued that different types of institutions constrain
Received: 7 November
Revised: 18 April 2016

Accepted: 18 May 2016

Online publication date: 22 July 2016 
and enable different forms of economic activity (Jackson \& Deeg, 2008). Most prominent among these has been the Varieties of Capitalism framework (Hall \& Soskice, 2001), which contrasted "liberal market economies" and "coordinated market economies." Meanwhile, other theories of comparative capitalism categorize countries in different ways based on diverse governance modes (Crouch, 2005; Crouch \& Streeck, 1997) or the concepts of National Business Systems (Whitley, 1999). The common objective of this comparative capitalisms literature has been to shed light on how the institutional diversity of advanced capitalist economies shapes economic and business outcomes.

A core argument of the literature is that institutions may generate distinct profiles of institutional comparative advantage in production, which manifest themselves in nationally distinct patterns of economic performance and specialization across different industrial sectors. For example, Schneider, Schulze-Bentrop, \& Paunescu (2010) explained relative export performance in high-tech and medium-tech industries based on different institutional characteristics of countries. Rather than a single "best" set of institutional arrangements, different types of institutions give rise to distinct forms of comparative advantage. Strong evidence in support of institutional comparative advantage would have important implications for government policy as well as the location choices of multinational enterprises (MNEs) seeking to avoid home country disadvantages, project competitive advantages related to their home country, or exploit complementary resources and knowledge related to host country institutional environments (cf. Jackson \& Deeg, 2008; Singh, 2007; Witt \& Lewin, 2007).

In this article we explore the question of institutional comparative advantage in relation to two arguments stemming from different branches of the comparative capitalisms literature. First, we test the well-known but widely contested hypothesis by Hall and Soskice (2001) that liberal market economies (LMEs) have an institutional comparative advantage in industries featuring radical innovation, whereas coordinated market economies (CMEs) have an institutional comparative advantage in industries with incremental innovation. This argument posits strong complementarities among relatively coherent sets of institutions that follow similar logics across all institutional domains of the economy. Second, we develop an alternative view that is based on conflictual logics of action, rather than coherence. We hypothesize that certain combinations of liberal market and coordinated logics across two or more institutional domains may enable institutional comparative advantage by compensating for institutional weaknesses inherent in "pure" configurations. For example, liberal corporate governance may provide an important external monitoring of strongly coordinated and otherwise insider-oriented governance institutions (Aoki, 2010). This view posits the potential for "beneficial constraints" based on institutional arrangements with conflicting logics.

The article explores these ideas empirically by comparing the trade patterns of countries during the period of 1995-2003. In particular, we use fuzzy-set qualitative comparative analysis (fsQCA) to test whether different configurations of institutions are sufficient for high performance in different sectors, characterized by either radical or incremental forms of innovation. We find that pure CMEs have comparative advantages in industries with incremental innovation. However, we do not find that LMEs have comparative advantages in industries with radical innovation. Rather, the results suggest that institutional comparative advantage involves very specific combinations of both liberal and coordinated types of institutions, which is in line with our own hypotheses.

We conclude with a discussion of implications and limitations of this study. In particular, our findings suggest the need to distinguish conceptually between complementarity and coherence of institutions and pay greater attention to how tensions resulting from opposing institutional logics can result in beneficial outcomes. By exploring the linkage between institutional configurations and economic outcomes, our article contributes to our understanding of the "so what?" of variety in capitalisms. Finally, our analysis shows that a number of countries have, over time, diverged from the commonly held notions about their institutional make-up. Germany, for instance, has evolved away from the pure-type coordinated market economy that it is commonly believed to represent.

\section{LITERATURE REVIEW AND HYPOTHESES}

\section{Comparative Capitalisms}

Renewed interest in institutions has led to a large and complex literature on comparative capitalisms focused on institutional diversity across national 
contexts (Jackson \& Deeg, 2008). Considerable agreement exists that national diversity exists across several core institutional domains such as education and skills formation, employment relations, financial system, interfirm networks, internal dynamics of the firm, ownership and corporate governance, and the institutions of the state itself (Witt \& Redding, 2013). Many studies explore how such differences cluster into distinct types of institutional configurations. Several competing typologies exist. For instance, Hall and Soskice (2001) distinguished CMEs and LMEs as two distinct forms of capitalism. Amable (2003) identified five types: market-based, Asian, Continental European, socialdemocratic, and Mediterranean. Whitley (1999) describes six major types of business systems: fragmented, coordinated industrial district, compartmentalized, state-organized, collaborative, and highly coordinated. Looking beyond the advanced industrialized countries, further types have been proposed (cf. Witt, Kabbach de Castro, Amaeshi, Mahroum, Bohle, \& Saez, 2015).

The challenge of creating theoretically rich and valid typologies is complicated by institutional change. While most comparative capitalism scholars reject the possibility of institutional convergence (Hall \& Soskice, 2001; Whitley 1999; Yamamura \& Streeck, 2003), many types of capitalism have undergone substantial liberalization. Thus a growing literature now focuses on the mechanisms of institutional change (Mahoney \& Thelen, 2009; Streeck \& Thelen, 2005) and the diverging trajectories in different types of capitalism (Hall \& Thelen, 2009; Streeck, 2008; Witt \& Lewin, 2007).

Meanwhile, research linking institutional differences to specific economic outcomes has remained surprisingly underdeveloped. First, a lack of consensus continues about relevant typologies. Consequently, scholars have continued to put energy into criticizing specific typologies (Allen, 2004; Blyth, 2003), validating typologies with empirical data (Brewster, Wood, \& Brookes, 2006) or extending these to new geographic contexts (Bohle \& Greskovits, 2009; Carney, Gedajlovic, \& Yang, 2009). Second, suitable measures of institutional diversity have limited availability. For instance, Varieties of Capitalism scholars have only produced an index of institutional diversity for 22 OECD countries for a single time point, the mid-1990s (Hall \& Gingerich, 2009). No time series is available, nor does the index cover countries outside the OECD. For the business systems approach (Whitley,
1999), no index is available. Some efforts have sought to overcome these shortcomings by drawing directly on the underlying institutional dimensions (e.g., Judge, Fainshmidt, \& Brown III, 2014; Schneider \& Paunescu, 2012). However, obtaining institutional measures with construct validity has proved difficult, especially for countries outside the OECD (Witt \& Redding, 2013). Together, these obstacles have limited the wider application of comparative institutional analysis in International Business. A substantial research agenda remains to understand how institutions shape the comparative institutional advantage of different countries in the world economy.

As a step to overcoming this challenge, this paper examines the key arguments from the Varieties of Capitalism framework that link institutions to comparative institutional advantage. Despite much criticism (Allen, 2004; Blyth, 2003) and alternative theoretical frameworks for comparing institutions (Amable, 2003; Crouch \& Streeck, 1997; Whitley, 1999), the Varieties of Capitalism framework continues to have a uniquely powerful hold on the field. Critics have made various important claims about the categorization of countries and how this changes over time: the parsimony of Varieties of Capitalism may overlook substantial institutional variety within the LME and CME categories (Yamamura \& Streeck, 2003), emerging and transition economies cannot be understood using this approach (Nölke \& Vliegenthart, 2009; Redding \& Witt, 2007), and its emphasis on complementarities and path dependence systematically overstates institutional stability and underestimates institutional change (Crouch, 2005). These criticisms notwithstanding, recent evidence supports the notion that advanced industrialized nations do indeed cluster very broadly into LMEs and CMEs (Witt \& Redding, 2013). More importantly, however, most critiques of Varieties of Capitalism do not center on its core claims about institutional comparative advantage.

Next, we turn to the main hypothesis of the Varieties of Capitalism approach and review empirical literature that tests these claims. After this, we will explore and develop an alternative hypothesis drawing on some alternative strands of the comparative capitalism literature.

\section{The Varieties of Capitalism Hypothesis: Comparative Advantage Through Coherence}

In developing the Varieties of Capitalism approach, Hall and Soskice (2001) proposed that the advanced 
industrialized societies fall into two main types: LMEs and CMEs. Firms in LMEs tend to rely more on liberal market mechanisms, while firms in CMEs tend to coordinate business transactions through non-market relationships. The prototypical LME, such as the US, features a market-driven financial system, flexible use of external labor markets, generalist education and training systems, low levels of networks and alliances among firms, and management-driven, top-down decision-making structures inside firms. The classic $\mathrm{CME}$, such as Germany around 1995, has a bank-led financial system providing patient capital, stronger internal labor markets based on employment protection, skills formation systems conducive to the development of specialized skills, high levels of networks and alliances among firms, and consensual decision-making inside firms bringing together management and labor. These institutional differences encourage firms to invest in and utilize transferable assets to a greater extent in LMEs, where institutions do not bind economic actors to long-term commitments but support their "keeping options open" to using the external market. By contrast, the use of relational assets in CMEs implies investments whose value is specific to the continuation of longterm relationships among company stakeholders. Such investments require different sorts of institutional support - such as protection of investments in firm-specific human capital and contracting arrangements, or mechanisms to govern collective action problems (e.g., free rider problems) and support wider patterns of cooperation across a network or industry.

The Varieties of Capitalism framework posits that LMEs and CMEs exhibit strong complementarities by being organized around a coherent institutional logic (Deeg, 2007). Complementarities exist where features of institutional structures reinforce each other by mutually generating increasing returns. Meanwhile, coherence is present where institutions follow the same market or coordinated logic across domains of the economy, such as corporate governance and employment relations. Since coherent institutions are hypothesized to uniformly support either transferrable or relational assets, the Varieties of Capitalism approach claims that institutions in different domains will complement one another by mutually reinforcing such investments. Based on their capacity to enable these different kinds of investments, Varieties of Capitalism argues that complementary sets of institutions favor certain patterns of economic activity over others that manifest in comparative strengths and weaknesses in different types of industries. By contrast, countries with lower levels of coherence - "mixed types" - are argued to lack the institutional complementarities needed for institutional comparative advantage.

Based on this logic, Hall and Soskice (2001) proposed that LMEs and CMEs would show distinct patterns of institutional comparative advantage for radical or incremental innovations. Hall and Soskice (2001: 38f.) defined radical innovation as "entail[ing] substantial shifts in product lines, the development of entirely new goods, or major changes to the production process," while incremental innovation is "marked by continuous but small-scale improvements to existing product lines and production processes." They argued that the combination of patient capital, long-term employment, and firm-specific skills in CMEs would enable more efficient production in industries with incremental patterns of innovation because the relative immobility of labor and capital in CMEs enabled and constrained firms to focus their efforts on improving existing lines of products. Meanwhile, fluid capital markets with short-term employment and general skills in LMEs would enable more efficient production in industries with radical patterns of innovation, as these conditions support firms using external markets to mobilize risky equity finance and workers with different skill sets, and thereby take advantage of new technological breakthroughs. Since comparative advantage is defined as the ability to make one product more efficiently than another, this suggests the presence of comparative advantage in industries drawing on incremental innovation in CMEs and radical innovation in LMEs. By the Law of Comparative Advantage (Dearsdorff, 1980), this advantage should be visible in international trade patterns. This leads to the following hypothesis:

H1 LMEs show trade patterns consistent with institutional comparative advantage in industries featuring radical innovation, whereas CMEs show trade patterns consistent with institutional comparative advantages in industries with incremental innovation.

\section{Prior Tests}

Despite its centrality, some fifteen years after the publication of Hall and Soskice's piece, H1 remains open territory. Attempts to test it have faced several interrelated conceptual and methodological 
challenges. First, mapping institutional diversity onto the two LME and CME categories is less straightforward than commonly assumed (see more generally Jackson \& Deeg, 2008). Different studies use different sets of indicators, or benchmark countries against assumed ideal-typical countries like Germany for CMEs (Allen \& Aldred, 2009; Schneider et al., 2010). Second, the concept of radical and incremental innovation has proven slippery. Operationalizing radicality requires a valid way of classifying industries according to different types of innovation. Most existing studies have relied on categorizations supplied by the OECD to describe high-tech or medium high-tech industries. This classification is based on R\&D intensity, which is a measure of investment or inputs into the innovation process rather the output of actual innovation. Third, empirical work has focused either on the influence of institutions on innovation patterns or the influence of institutions on export success, but missed what we see as the core of the Varieties of Capitalism hypothesis - namely, the idea that the influence of institutions on trade outcomes is mediated by or contingent upon types of innovation. Cross-country differences exist in the patterns of radical or incremental innovation (Furman, Porter, \& Stern, 2002), and this capacity does relate to institutional features of the economy, such as employment relations (Bassanini \& Ernst, 2002). However, we see this as a separate debate. In our view, the core of the Varieties of Capitalism hypothesis actually revolves around comparative advantage in products as the dependent variable, rather than $R \& D$ spending or patents. The Varieties of Capitalism argument stresses the ability of firms to draw on these innovations in the productive process, not their ability to make radical innovations. Firm-level studies using both approaches have found these to be potentially complementary, but in fact very distinct, phenomena (Herrmann \& Peine, 2011).

To our knowledge, only four major published studies have attempted to explicitly test the Varieties of Capitalism hypothesis. Taylor (2004) and Akkermans, Castaldi, \& Los (2009) examined innovation patterns as visible in patent data. While Taylor found no support of the hypothesis, Akkermans and colleagues claimed qualified support. However, both papers tested only the ability of economies to produce radically innovative patents and not actual institutional comparative advantage, which is the outcome of interest in this paper. Schneider et al. (2010) as well as Schneider and
Paunescu (2012) used trade outcomes to claim qualified support of the Hall and Soskice hypothesis. Both papers relied on exports as a measure of comparative advantage. However, as the case of electronics in China illustrates (e.g., Redding \& Witt, 2009), high levels of exports in an industry may occur on the back of high levels of imports of high value added inputs in the same industry, in which case only a small proportion of the value of the exports in these industries are produced in the respective country. These imports need taking into account to establish whether a comparative advantage exists. The two papers also relied on OECD classifications of research intensity to express radicality. However, radicality is an output of research activity, while research intensity is an input measure based on $R \& D$ spending relative to industry size. In sum, prior works have either sought to explain innovation patterns rather than comparative advantage, or suffered from issues with construct validity of key variables. As will be explained in the methodology section, this article will offer a more comprehensive test of $\mathrm{H} 1$ than the previous literature.

\section{Alternative Hypothesis: Complementarities Through Beneficial Constraints}

The Varieties of Capitalism approach has assumed that complementarities require coherence of institutions (e.g., pure LME types, where all institutions are liberal). The underlying logic stems from the concept of complementarities as developed in economics (Milgrom \& Roberts, 1994, 1995), whereby investments in transferable assets in one institutional domain are complemented by transferable assets in other domains. For example, portable skills are expected to increase in value for workers if firms also have corporate governance arrangements whereby capital investment is shifted rapidly from one firm to another. Conversely, longterm relational employment relationships are presumed to benefit from "patient capital" of coordinated blockholders, whose long-term strategic investment in the firm will protect the firm-specific skill investments of workers.

Based on this reasoning, Varieties of Capitalism implies a very restrictive view of how institutions combine. Comparative advantage relates to the coherence of incentives provided by the set of institutions within a country, and thus complementarities only form when institutions cluster into only two ideal-typical patterns. We believe that these assumptions about complementarities 
are problematic and at odds with empirical work linking comparative advantage to more complex or hybrid combinations of coordinated and liberal institutions (Boyer, 2004). We thus draw on a stream of the comparative capitalisms literature grounded in economic sociology to develop an alternative set of hypotheses regarding complementarities based on opposing institutional logics.

Our intuition here is to see complementarities as essentially grounded within political projects. Crouch (2005) argued that institutions may have positive effects by compensating for the weaknesses of other institutions. For example, political systems often utilize competing institutional logics that serve as checks and balances on one another - such as when the rule of law in the judiciary acts to balance the logic of majority rule in the legislature. Along these lines, sociological theories of comparative capitalism have observed that opposing logics or principles of social organizations may be useful complements (Crouch, Streeck, Boyer, Amable, Hall, \& Jackson, 2005; Höpner, 2005). Here the political economy of capitalism involves not simply a choice between coordination or liberal markets, but reflects political coalitions and compromises that seek a balance between them. The interests and relative powers of different actors groups, particularly corporate stakeholders, come into play. Liberal markets produce winners and losers, also generating counter-movements seeking to contain the influence of markets through efforts of coordination and social protection (Block \& Somers, 2014). In terms of the CME and LME typology, this perspective implies that mixed cases or hybrids may have beneficial characteristics. For example, Boyer (2004) showed that Nordic economies achieved economic growth in emerging ITC sectors based on a specific combination of liberal markets and coordinated institutions. However, whether or not mixed cases work well together depends on the extent to which the specific combination of market and coordinated logics across two or more domains may help compensate for one another. Unfortunately, the comparative capitalism literature offers only scant theorizing about specific hybrid combinations.

Based on these considerations, we develop two hypotheses whereby coordinated institutions help to prevent or remedy market failures in liberal settings or, following the inverse logic, liberal market institutions help to remedy problems of rigidity in highly coordinated settings. Here opposing institutional logics complement one another.
To elaborate this idea, we focus on the two most salient stakeholders of the firm: shareholders and employees. Here we see a potential counterbalancing role to be played by each of these groups. Shareholders may benefit from liberal corporate governance and establish this as a counterweight to more coordinated institutions. Likewise, employees may favor more coordinated employment relations and benefit from coordination as a counterweight to otherwise liberal institutions. These mixed configurations reflect a compromise or balancing between opposing logics, whereby the interests of one key stakeholder are addressed within an overall context that is more hostile to their interests.

In developing these hypotheses, we turn to the concept of "beneficial constraints" in economic sociology (Streeck, 1997). Streeck argues that socially institutionalized constraints on the rational voluntarism associated with markets may be economically beneficial. Normative constraints and social obligation are needed to correct market failures, and thus also enable economic actors to develop and protect collective goods or commitments to stakeholders that would otherwise fall victim to hyper-rational economizing. Rather than allowing economic actors to pursue their given preferences, institutions may transform the identities and interests of actors by constraining their pursuit of short-term aims and leading them to search for new and alternative strategies that are legitimate in their institutional context. In doing so, institutional constraints can turn institutions into beneficial resources ${ }^{2}$ by simultaneously enabling new forms of coordination and cooperation, thus potentially attaining higher levels of economic performance than might be possible in their absence. By constraining certain market behaviors, institutions may help create or protect critical resources based on coordinated investments by stakeholders. As Streeck argued: "Beneficial constraint...is a dialectical concept, suggesting a relationship of both mutually subversive and mutually supportive conflict between the economic and the social, ruling out any lasting harmony between the two" (Streeck, 1997: 207). Importantly, this view of institutions goes beyond the notion of property rights or embeddedness in social networks that facilitate market exchange. Rather, institutions act as constraints on markets, on the one hand, but serve to stabilize them, on the other - thus suggesting their Durkheimian character (Jackson \& Muellenborn, 2012). 
Viewed from this perspective, the coherent set of market-oriented institutions characterizing LMEs may have inherently self-destructive tendencies. As markets across different domains of the economy reinforce one another by creating incentives for greater market-orientation, these markets may become overheated or hyper-rational. Time horizons may become too short and market failures may occur in relation to long-term financial investments, development of cooperative supplier relationships, or fostering of firm-specific skills in productive capabilities (Campbell, 2011; Jackson \& Petraki, 2010). Positively, firms in LMEs may respond quickly to radical innovations by shifting their investments in markets for capital and labor. However, left unconstrained, firms may also be likely to focus on predatory responses, such as using mergers and acquisitions to obtain new technologies or protect market shares or aggressively restructure corporate hierarchies by shedding employees and boosting shareholder returns. As a result, firms may be unable to capitalize on radical innovations by developing related firm-specific advantages that lead to sustained comparative advantages, as suggested by the resource-based view and other theories (Newbert, 2007).

These deficits of purely liberal markets are likely to be most acute in the area of employment relations. Employee skills and organizational capabilities based upon them are essential for comparative advantage during times of discontinuous change (Aoki \& Jackson, 2008; Rajan \& Zingales, 2000). In particular, firms entering and expanding new lines of business as a result of radical innovation will need skilled employees with sufficient understanding of the workings of the firm (i.e., firm-specific skills) to capitalize on the opportunities offered by new technology. While active external labor markets may help firms gain access to new skills, left fully to the logic of the market, firms are also likely to suffer from substantial problems to retain key employees through periods of dynamic change. Economic sociology has thus suggested that markets need to be embedded within social relations, not only for moral or political reasons, but for economic ones. Institutional constraints imposed by coordination may be beneficial for markets precisely because they curtail the opportunism and hyper-rationality that lock actors into potential market failures due to collective action problems. Many countries in Europe thus restrict competition between firms based on wages through institutions that regulate pay at sectoral or even national level. Likewise, Japanese firms utilize strong norms of lifetime employment for their core workforce while limiting external labor markets to a very narrow range of specialists or to temporary employees. While economists usually see these restrictions as politically motivated, by the logic of beneficial constraints, they may be economically beneficial by providing an institutional basis on which companies can develop and retain necessary resources.

Rather than complementarities based on coherence, we expect that firms facing radical innovation in countries with liberal market institutions in most domains may benefit from complementary institutions that support coordination in employment relations. A combination of liberal and coordinated institutions may be beneficial for dealing with radical innovation by providing for both flexibility in restructuring of economic organization as well as trust and coordination to solve problems of asymmetric information or hold-up. Applying the same logic as Hall and Soskice (2001) linking these benefits to comparative advantage, we thus posit the following:

H2 Countries with coordinated institutions in employment relations and liberal institutions in other domains will show trade patterns consistent with comparative advantage in industries with radical innovation.

Beneficial constraints also extend to a second argument. Similar to the inherent problems with unconstrained market-oriented transactions, high levels of coordination may lead to an overextension of relational logics. To the extent that coordination becomes strongly self-reinforcing, firms may lack incentives to take risks and enter into new lines of business - employment is long-term, firm-specific skills are well developed, workers participate in firm decision-making, inter-firm relations rely on stable partners, and owners take a long-term strategic view. These patterns may be beneficial in stable industry environments characterized by low levels of innovation or even incremental patterns, as hypothesized by Varieties of Capitalism. However, it seems unlikely to these institutional arrangements can support adjustments to more radical and discontinuous forms of innovation (Witt, 2006).

The potential deficits of high coordination may create particular problems for shareholders, who 
are disadvantaged by low competitiveness. Consequently, we see more liberal forms of corporate governance as having potential to exert a counterbalancing effect on high coordination and thus to represent an economically beneficial compromise between competing logics. Here firms benefit from high coordination across different domains, including employment relations, and develop strong capabilities based on their human assets and relational linkages to other firms. However, a literature on hybrid forms of corporate governance suggests that increasing pressures from capital markets may lead stakeholder-oriented firms to take bolder and faster adjustments to changes in technology and product markets (Vitols, 2002, 2004). For example, Aoki (2010) argues that external monitoring of internal linkages of corporate organization may be beneficial in giving corporate insiders important signals about their overall business strategy and help benchmark their efforts against competitors. Unlike monitoring by "patient" investors, a more liberal market-oriented process may be a beneficial resource for investors seeking to constrain the tendencies toward stagnation among corporate insiders, such as employees and managers. While commitments to corporate stakeholders remains strong, some pressure from capital markets and influence from owners may help to catalyze more dynamic, albeit "negotiated" responses to radical innovations through more discontinuous management strategies or changes in production technologies. Indeed, a growing literature on the relation between corporate governance and employment patterns suggest more complex relationships between these variables than found in the Varieties of Capitalism literature (Gospel \& Pendleton, 2003, 2005; Höpner, 2005). Despite their potential to destabilize commitments to stakeholders, liberal market institutions in corporate governance may also potentially help counterbalance risk averse tendencies of corporate insiders, thus paradoxically helping to catalyze their dynamic potential in terms of functional flexibility and ability to foster trust, but here in the service of adjustments to radical innovation. Applying the same logic about the linkage to comparative advantage and trade, we thus posit:

H3 Countries with liberal institutions in corporate governance and coordinated institutions in other domains will show trade patterns consistent with comparative advantage in industries with radical innovation.

\section{METHODOLOGY, DATA AND CALIBRATION}

\section{Methodology: fsQCA}

We used fsQCA in Stata (StataCorp, 2013) as provided by Longest and Vaisey (2008). Qualitative comparative analysis draws on Boolean algebra to determine which configurations of causal conditions are related to an observed outcome (Ragin, 2000). The method is increasingly used in the business and management literature (e.g., Bell, Filatotchev, \& Aguilera, 2013; Crilly, 2011; Fiss, 2011; Judge et al., 2015; Schneider et al., 2010).

We adopted fsQCA because of its distinct advantages for studying institutional complementarities (Jackson \& Ni, 2013). First, fsQCA is well suited to capture conjunctural types of causation that underlie theories of complementarity. Complementarities are based on specific configurations where multiple causal factors combine to produce an outcome. Traditional statistical methods model "net effects" of single variables, while holding other factors constant. While interaction effects can capture specific conjunctions, such as radical innovation with institutional coordination, these methods are not well suited to more complex conjunctions. Consequently, most work on comparative capitalism has used factor analysis to simplify institutional configurations into highly simplified one-dimensional constructs (Hall \& Gingerich, 2009) or group countries into a limited number of types (Amable, 2003), at the risk of losing important distinctions in the process. fsQCA does not require such simplifying steps. Second, fsQCA can identify how multiple different combinations of independent variables can produce the same outcome (equifinality). Third, fsQCA evaluates set theoretical relationships, rather than correlations among different factors. This underappreciated facet allows for the possibility of asymmetrical relationships, whereby high and low values of the outcomes are driven by different causal conditions. For example, if low coordination and radicality are jointly sufficient for high performance outcomes, it does not follow that coordination is sufficient for outcomes of low performance. Finally, the method is not sensitive to outliers because it does not assume an underlying probability distribution (Fiss, 2011).

\section{Sample and Data Structure}

Our dataset consists of 2772 observations, made up of 14 industries at the 2-digit ISIC-3 level in 22 OECD countries, with annual observations from 
1995 through 2003. Each case is a particular industry for a given country and year. The choice of countries, industries, and years was affected by data availability as explained below.

\section{Outcome Measure: Contribution to the Trade Balance}

Our outcome measure was the contribution to the trade balance for manufacturing industries. It is based on the "Law of Comparative Advantage" in economics (Dearsdorff, 1980), which states that comparative advantages in manufacturing should be revealed in trade patterns. Much of the economics literature has measured revealed comparative advantage using the Balassa (1965) index, which compares a country's export market share in a given industry with the average export market share of all countries. We followed an alternative calculation used by the OECD (2003) that we believe to have higher construct validity, as we will explain below.

For each country, the contribution to the trade balance (CTB in the formula) in the OECD conceptualization and as used in this article is computed as follows:

$$
C T B=\left(X_{i}-M_{i}\right)-(X-M) \frac{\left(X_{i}+M_{i}\right)}{(X+M)},
$$

where $\left(X_{i}-M_{i}\right)$ is the observed trade balance in industry $i$ in the given country and the remainder for the formula is the theoretical trade balance for this same industry $i$ in the same country (OECD, 2003: 150). To make the results comparable across countries, they are expressed a percentage of total trade for the respective country. A positive value denotes the presence of a comparative advantage, a negative value, of a comparative disadvantage for that country in a particular industry (OECD, 2013). We obtained these data from the OECD (2013).

This measure improves over the Balassa index in two important ways. First, it takes into account the level of imports in a given industry. While the Balassa index focuses entirely on exports and thus cannot distinguish whether a country has a high export market share because it produces much of the value-added itself (a sign of comparative advantage) or because it imports and re-exports (as in the case of China already discussed), our measure can distinguish between these two cases. Second, the Balassa index is a measure of competitive advantage rather than comparative advantage. Comparative advantage exists within each country with respect to other industries. This implies a need to compare within countries, as our measure does, rather than across countries, as the Balassa index does. For example, assume that country A has two industries, $\mathrm{X}$ and $\mathrm{Y}$, and is better at producing goods in these industries than any other country in the world. This would give it a competitive (absolute) advantage relative to other countries, which the Balassa index would pick up as an advantage in both industries. However, if country $\mathrm{A}$ is better at producing $\mathrm{X}$ than at $\mathrm{Y}$, we can say that it has a comparative advantage at $X$ over $Y$. The Balassa index would miss this, while our preferred measure would pick this up. For robustness testing, we will later check our results against those of the Balassa index.

In choosing our industries, we omitted low technology industries, such as food and beverages, textiles, and wood and cork. Low technology industries are defined by the lowest research activity, which implies a weak link between innovation and resultant comparative advantage. Our analysis thus focused on low-medium technology, medium-high technology, and high technology sectors. Since the contribution to the trade balance is likely to manifest itself with a delay after an invention occurred, our analysis used a lead-time of one year relative to the causal conditions (i.e., the contribution to the trade balance in year 2004 will be analyzed with respect to institutional factors for 2003).

\section{Causal Conditions: Indicators of Radicality and Institutional Coordination}

\section{Indicators of Radicality}

Following Akkermans et al. (2009), we calculated three distinct, patent-based measures to gauge the extent of radical innovation in a given society. In line with the prior literature, incremental innovation is operationalized as the inverse of radical innovation - innovations that are not radical are assumed to be incremental. While we will later question this assumption, we retained it since no established measure of incremental innovation exists in the literature.

In our first step, we obtained all entries from 1990 through 2005 of the NBER Patent-Citations Data File (Hall, Bessen, \& Thoma, 2011). This database contains the patent number and three indicators of radicality for each US patent issued during this period: number of citations received, generality, and originality. The number of citations 
received operationalizes the concept of radicality by measuring the impact on future technological development, as expressed in subsequent citations by other patents. Generality refers to the propensity of basic innovation to diffuse to many different industries and areas of technology, that is, their versatility. Originality expresses the idea that truly radical innovations are likely to cite patents from different areas of technology. Further explanations of these measures are contained in the works of Hall, Jaffe, \& Trajtenberg (2001) and Akkermans et al. (2009).

For all three measures, the innovation literature has interpreted higher numbers to indicate higher levels of radicality (Akkermans et al., 2009). We believe that of the three measures, the number of citations received is likely to be closest to a valid indicator of radicality. Similar to citations to scholarly articles, citations to patents indicate their impact. Just as highly cited articles are relatively more likely to be in some way seminal than less cited pieces, patents with higher citations counts are likely to have a greater impact on the course of technology development and thus represent radical steps in technological development. We are less convinced of the construct validity of the other two measures. Breakthrough ideas in one area do not necessarily have to be of interest to other areas, nor do they need to assemble insights from many different preexisting areas. Despite our doubts, we retained both generality and originality for robustness tests.

The raw data required two further steps for our purposes. First, the generality and originality measures are defined as Herfindahl indexes and therefore not given for patents that received no citations or contained no citations. In these cases, we assigned a value of 0 for each measure. Second, both measures are biased downward for patents involving small numbers of citations (Hall, Jaffe, \& Trajtenberg, 2001). We corrected for this bias as proposed in Hall, Jaffe, \& Trajtenberg (2001).

Since our outcome measure is categorized by industries following the ISIC 3 classification scheme, we next matched each patent with one or several ISIC codes. The United States Patent and Trademark Office (USPTO) assigns each patent to one or several industries to which the patent is likely to be relevant. While the original assignment scheme is incompatible with ISIC classifications, the USPTO identifies the SIC codes for each patent in its PATSIC-CONAME database. We obtained the year 2008 version of the database and matched the contents of the NBER database with the PATSICCONAME database using patent numbers, which are contained in both databases.

We calculated the relative proportions of radically innovative patents by industry and country for each of the three measures of radicality. Similar to Akkermans et al. (2009), we define a patent to be radically innovative if it scores higher than the 95th percentile for a given measure. For instance, if the 95th percentile for citations received in the pharmaceuticals industry was 15 , we would count as radical all patents with more than 15 citations received. We consequently calculated the threshold separately for each year because the year of publication of a patent affects how many citations it has received, with younger patents on average receiving fewer citations than older ones.

In the final step, we calculated the proportion of patents above the threshold in each country, industry and year. To generate a more stable picture, we assigned to each observation the three-year average of these proportions from $t-2$ years to $t$. We discarded data from 2004 and 2005 because the database ends in 2005, which means that there was insufficient time for citations from these two years to receive sufficient numbers of citations for discriminating between radically and incrementally innovative patents. Given the strong interest in innovation patterns in the Varieties of Capitalism debate, Table 1 shows the cross-tabulation of radicality, using the citations received indicator, by country and industry.

\section{Institutional Indicators}

The starting point in understanding institutions was past work categorizing countries into either LME or CME types of capitalism. However, different studies based classifications on different institutional domains and have made different assumptions about how institutions combine into these broader types. For example, Hall and Gingerich (2009) used confirmatory factor analysis to derive a coordination index for 20 advanced industrialized economies based on three corporate governance and three employment relations variables. However, this approach covered only two of the five institutional domains discussed by Varieties of Capitalism (Hall \& Soskice, 2001). In addition, the construction of a single index assumes that complementarities are achieved through cohesion (all domains being either fully coordinated or fully liberal), an assumption this paper seeks to relax and test $(\mathrm{H} 2, \mathrm{H} 3){ }^{3}$ 
Table 1 Proportion of radical patents by citations received, by country and industry, 1995-2003

\begin{tabular}{|c|c|c|c|c|c|c|c|c|c|c|c|}
\hline Industry & AT & $\mathrm{AU}$ & $\mathrm{BE}$ & $\mathrm{CA}$ & DK & $\mathrm{FI}$ & FR & $\mathrm{DE}$ & GR & IE & IT \\
\hline Aircraft, spacecraft & 0.012 & 0.051 & 0.056 & 0.064 & 0.127 & 0.000 & 0.007 & 0.043 & 0.000 & 0.000 & 0.031 \\
\hline Basic metals & 0.000 & 0.094 & 0.019 & 0.027 & 0.000 & 0.000 & 0.034 & 0.036 & 0.000 & 0.056 & 0.058 \\
\hline Chemicals other than pharmaceuticals & 0.020 & 0.037 & 0.020 & 0.046 & 0.027 & 0.032 & 0.028 & 0.030 & 0.000 & 0.105 & 0.018 \\
\hline Electrical machinery & 0.007 & 0.046 & 0.034 & 0.095 & 0.008 & 0.034 & 0.026 & 0.020 & 0.000 & 0.016 & 0.019 \\
\hline Machinery & 0.017 & 0.036 & 0.028 & 0.053 & 0.015 & 0.023 & 0.017 & 0.022 & 0.000 & 0.042 & 0.012 \\
\hline Medical, precision, optical equipment & 0.007 & 0.042 & 0.009 & 0.052 & 0.043 & 0.015 & 0.019 & 0.018 & 0.000 & 0.099 & 0.008 \\
\hline Metal products & 0.039 & 0.038 & 0.038 & 0.066 & 0.025 & 0.016 & 0.030 & 0.029 & 0.000 & 0.000 & 0.024 \\
\hline Motor vehicles & 0.041 & 0.018 & 0.028 & 0.084 & 0.028 & 0.019 & 0.024 & 0.037 & 0.000 & 0.053 & 0.020 \\
\hline Non-metallic products & 0.006 & 0.079 & 0.016 & 0.067 & 0.023 & 0.026 & 0.030 & 0.023 & 0.000 & 0.000 & 0.018 \\
\hline Office, accounting, computing equipment & 0.000 & 0.051 & 0.026 & 0.065 & 0.000 & 0.026 & 0.011 & 0.010 & 0.000 & 0.018 & 0.006 \\
\hline Other transport equipment & 0.015 & 0.037 & 0.000 & 0.041 & 0.000 & 0.000 & 0.024 & 0.060 & 0.000 & 0.000 & 0.048 \\
\hline Pharmaceuticals & 0.018 & 0.022 & 0.018 & 0.043 & 0.023 & 0.037 & 0.025 & 0.021 & 0.000 & 0.100 & 0.013 \\
\hline Radio, TV, communication equipment & 0.008 & 0.048 & & 0.072 & 0.002 & 0.066 & & & 0.000 & 0.044 & 0.004 \\
\hline Rubber, plastic & 0.036 & 0.038 & 0.024 & 0.059 & 0.031 & 0.026 & 0.033 & 0.027 & 0.000 & 0.035 & 0.027 \\
\hline Average & 0.016 & 0.046 & 0.024 & 0.060 & 0.025 & 0.023 & 0.023 & 0.028 & 0.000 & 0.041 & 0.022 \\
\hline Industry & JP & $\mathrm{NL}$ & NO & NZ & $\mathrm{PO}$ & $\mathrm{KR}$ & ES & SE & $\mathrm{CH}$ & UK & US \\
\hline Aircraft, spacecraft & 0.073 & 0.026 & & & & & & & & & 0.065 \\
\hline Basic metals & 0.038 & 0.073 & 0.000 & 0.000 & 0.000 & 0.010 & 0.111 & 0.000 & 0.037 & & 0.081 \\
\hline Chemicals other than pharmaceuticals & 0.031 & 0.027 & 0.032 & 0.033 & & 0.0 & & & 0.041 & & 0.072 \\
\hline Electrical machinery & 0.038 & 0.020 & 0.021 & 0.082 & 0.000 & 0.021 & 0.022 & 0.021 & 0.015 & 0.035 & 0.076 \\
\hline Machinery & 0.057 & 0.023 & 0.015 & 0.009 & 0.000 & 0.025 & 0.018 & 0.018 & 0.014 & 0.029 & 0.077 \\
\hline Medical, precision, optical equipment & 0.017 & 0.033 & 0.024 & 0.005 & 0.000 & 0.010 & 0.000 & 0.022 & 0.029 & 0.025 & 0.074 \\
\hline Metal products & 0.054 & 0.038 & 0.006 & 0.000 & 0.000 & 0.034 & 0.024 & 0.031 & 0.022 & 0.035 & 0.077 \\
\hline Motor vehicles & 0.049 & 0.014 & 0.065 & 0.000 & 0.000 & 0.010 & 0.016 & 0.032 & 0.060 & 0.022 & 0.078 \\
\hline Non-metallic products & 0.042 & 0.052 & 0.000 & 0.000 & 0.000 & 0.033 & 0.009 & 0.063 & 0.024 & 0.026 & 0.080 \\
\hline Office, accounting, computing equipment & 0.011 & 0.021 & 0.139 & 0.037 & 0.000 & 0.008 & 0.037 & 0.038 & 0.005 & 0.027 & 0.077 \\
\hline Other transport equipment & 0.076 & 0.000 & 0.000 & 0.000 & 0.000 & 0.004 & 0.000 & 0.007 & 0.000 & 0.031 & 0.071 \\
\hline Pharmaceuticals & 0.011 & 0.055 & 0.093 & 0.028 & 0.000 & 0.019 & 0.025 & 0.057 & 0.052 & 0.045 & 0.074 \\
\hline Radio, TV, communication equipment & 0.026 & 0.015 & 0.058 & 0.019 & 0.000 & 0.021 & 0.022 & 0.058 & 0.014 & 0.035 & 0.074 \\
\hline Rubber, plastic & 0.039 & 0.036 & 0.005 & 0.000 & 0.000 & 0.033 & 0.034 & 0.063 & 0.034 & 0.030 & 0.080 \\
\hline Average & 0.040 & 0.031 & 0.033 & 0.015 & 0.003 & 0.019 & 0.025 & 0.034 & 0.025 & 0.032 & 0.075 \\
\hline
\end{tabular}

We thus considered all five domains: corporate governance, inter-firm relations, hierarchies within firms, employment relations, and education. For each institutional domain, we conceptualized of institutions as varying along a single dimension spanning between liberal institutions characterized by a high use of market relationships or transferable assets and coordinated institutions characterized by high use of long-term strategic relationships or relationship-specific assets. We adopted a separate indicator for each and later will explore the different ways in which they combine into a number of complex configurations.

In terms of corporate governance, we used three indicators. First, an index of legal rules for shareholder protection measures whether laws in a country adopt particular protections related to disclosure, voting rights, and so forth (La Porta, Lopez-de-Silanes, Schleifer, \& Vishney, 1998). Since no alternative suitable measures exist, we took the original indicator derived by LLSV (La Porta, Lopezde-Silanes, \& Shleifer, 1999) and an updated measure for 2003 (Botero, Djankov, La Porta, Lopez-deSilanes, \& Shleifer, 2004), interpolating annual values based on the movement between these two periods. Shareholder protection indicates the degree to which business firms are likely to have a liberal orientation toward shareholder control. Second, we obtained stock market valuation as a percentage of GDP from OECD statistics to capture the salience of the stock market for company financing. Third, we measured the dispersion of share ownership by the percentage of large firms in each country that have a blockholder with an ownership stake of $10 \%$ or greater. We used the LLSV indicator of ownership dispersion based on the percentage of large firms without an owner holding a $10 \%$ stake or more, and calculated our own data for 2003 using ownership data from the ownership module of Thomson Banker One. We 
interpolated annual data based on the year-to-year changes between these two dates. High blockholding is associated with coordination.

For inter-firm relationships, we used two indicators based on merger and acquisition activity from the Capital IQ database. First, the number of merger and acquisition deals by acquiring firms in each country indicates the use of the market in governing relationships between firms. While we lack internationally comparable measures of coordination such as that achieved through long-term relational contracts in buyer-supplier relations, prior literature (Schneider \& Paunescu, 2012) suggested that mergers and acquisitions indicate that firms seek to obtain assets from target firms through a market-driven acquisition of ownership rights. Second, the proportion of merger and acquisition deals that take the form of a full-scale merger indicates the use of strong market relationships. Mergers and acquisitions may involve arms' length transactions, where control is purchased and leads to the dissolution of a target firm, or acquisitions of minority ownership stakes. In the latter case, the target firms remain legally independent but enter into a coordinated long-term relationship with the acquiring firm.

For firm hierarchies, we examined the degree of employee participation at the level of corporate boards and through works councils and similar labor-management consultation bodies. Boardlevel employee representation has been categorized based the percentage of employees on the board and on whether codetermination requirements apply broadly to all large private companies, are restricted to public corporations, or do not exist at all (Jackson, 2005). Strong legal rights to employee representation on boards indicate long-term relational coordination of firm operations between management and employees. In addition, many countries anchor employee participation at the level of the establishment or even workplace in the form of works councils. We measured work council rights by the rights to information, consultation or even codetermination of managerial decisions, as well as whether these rights pertain to social or also economic matters of the enterprise (Visser, 2011).

In terms of employment relations, we used three indicators. First, we considered the duration of tenure with a particular employer. Unfortunately, existing data from the OECD do not permit detailed cross-national comparisons of average job tenure or the proportion of employees with very high tenure.
Thus we examined only the proportion of employees with short job tenure of less than one year. While all countries have some new hires, a high proportion of new hires indicate a more liberal market-oriented to employment practices, whereas a low proportion indicates that employment may be more long-term and coordination. Second, we examined the strictness of employment protection for regular employees based on well-known OECD indices. Greater difficulty in firing workers indicates again a higher degree of coordination in employment relations. Finally, we measured the degree of coordination in wage bargaining across firms, industries and national levels. This indicator shows the degree to which firms engage in individualized market transactions in setting wages, or whether these are coordinated with other employers in the same industry or even nationally (Visser, 2011).

Finally, we used two indicators to examine the characteristics of education and training institutions. We drew on OECD statistics on the proportion of graduates from different types of educational institutions within the wider population. First, we took the share of graduates from upper secondary or post-secondary non-tertiary as a broad indicator for occupationally-based vocational training (Schneider et al., 2010). Second, we used university training, as measured by the number of graduates from university as a share of the population in the typical graduation age range, as an indicator of general training (Schneider et al., 2010). Taken together, these indicators show the importance of two pathways toward skilled workforces based either on more occupationally based and thus relationship-specific training in particular occupations, which reflect higher degrees of coordination, or on university-based education that offers more general set of skills that tend to be portable across firms or very broad range of jobs according to individual career trajectories.

Table 2 presents an overview of the descriptive statistics for all indicators used in the study.

\section{Calibration}

fsQCA requires calibration of all data into set membership scores that fall between 0 (full absence of the given causal condition) to 1 (full presence) (Ragin, 2008). Calibration combines information about qualitative differences in kind (e.g., countries with or without employee participation in firm hierarchies) with information about differences in degree (e.g., different degrees of participation). 
Table 2 Descriptive statistics

\begin{tabular}{|c|c|c|c|c|c|c|}
\hline & Indicator & $\mathrm{N}$ & Mean & SD & Min & Max \\
\hline 1 & Shareholder protection & 198 & 3.24 & 1.1 & 0 & 5 \\
\hline 2 & Dispersion of control & 198 & 0.33 & 0.24 & 0 & 0.9 \\
\hline 3 & Size of stock market & 198 & 78.5 & 54.19 & 8.92 & 317.03 \\
\hline 4 & Mergers and acquisitions & 198 & 0.24 & 0.27 & 0 & 1.1 \\
\hline 5 & Mergers & 198 & 0.38 & 0.19 & 0 & 1 \\
\hline 6 & Wage coordination degree & 198 & 0.18 & 0.06 & 0.08 & 0.41 \\
\hline 7 & Short-term employment & 198 & 3.07 & 1.25 & 1 & 5 \\
\hline 8 & Employment protection & 198 & 2.06 & 0.86 & 0.17 & 4.33 \\
\hline 9 & Board-level codetermination & 198 & 0.43 & 0.39 & 0 & 1 \\
\hline 10 & Works council rights & 198 & 1.19 & 1.1 & 0 & 3 \\
\hline 11 & Occupational training & 198 & 43.89 & 19.25 & 2 & 82 \\
\hline 12 & University training & 198 & 29.5 & 9.7 & 9 & 53.3 \\
\hline 13 & Radicality, citations received & 198 & 0.03 & 0.04 & 0 & 0.42 \\
\hline 16 & Radicality, generality & 198 & 0.04 & 0.04 & 0 & 0.48 \\
\hline 17 & Radicality, originality & 198 & 0.07 & 0.06 & 0 & 0.67 \\
\hline 14 & Contribution to the trade balance & 198 & -0.12 & 1.72 & -7.33 & 10.9 \\
\hline 15 & Balassa index & 198 & 0.92 & 0.73 & 0 & 6.32 \\
\hline
\end{tabular}

Ragin (2008) stresses using external benchmarks rather than sample variance in defining thresholds for set membership. Rather than assuming that being "above average" or "below average" on a particular indicator is sufficient for having high or low membership in a particular set, the extent of membership depends on theoretical criteria and substantive knowledge of the cases at hand. While we adopt this qualitative approach to data calibration, the results of our calibration scoring correlate at levels of $95 \%$ or above with scores derived from more automated coding procedures such as using a standardized rank ordering of cases.

Table 3 presents a summary of all data sources, the calibrations of each institutional indicator and construction of higher-order constructs used in the empirical analysis.

We combined the indicators into five higherorder constructs, one for each domain, taking the minimum score among the selected indicators for each country (on set operators logical AND and OR, see Ragin, 2008), whereby higher membership were coded to indicate greater coordination. Firm hierarchy is the membership in the set of countries with both high coordination for board codetermination and works councils. Inter-firm relations are highly coordinated in countries with both low mergers and acquisitions per capita and where full mergers are not the predominant form of mergers and acquisitions. Education is highly coordinated in countries that have high occupational training and low university education. Membership in the set of countries with coordinated corporate governance was based on three indicators: the absence of dispersed ownership and either weak stock markets or weak shareholder rights. Before combining with the ownership condition, we first took the maximum score for membership in the set of countries with an absence of stock market activity or weak shareholder rights. We treat these as functionally equivalents for coordination, since the absence of either condition means that managers are unlikely to feel strong pressures from shareholders. Turning to employment relations, high coordination is present in countries with coordinated wage bargaining and either long employee tenures or strong employment protection. Again, the outcomes of high tenure or legal protection of regular workers are treated as functionally equivalent indicators of long-term employment relations.

Table 4 presents a summary overview of our calibrated measures for each country, showing whether they fall into more coordinated or more liberal "types" for each institutional domain based on the average scores across the period 1995-2003. In our analysis, we did not use these averages but yearly indicators, since many countries actually changed configurations during this time period.

To calibrate set membership for radicality, we considered membership in the set of industries with high radicality based on the proportion of patents that are highly cited. Similar to the contribution to the trade balance measure, we calibrated radicality in terms of the concentration of radical 


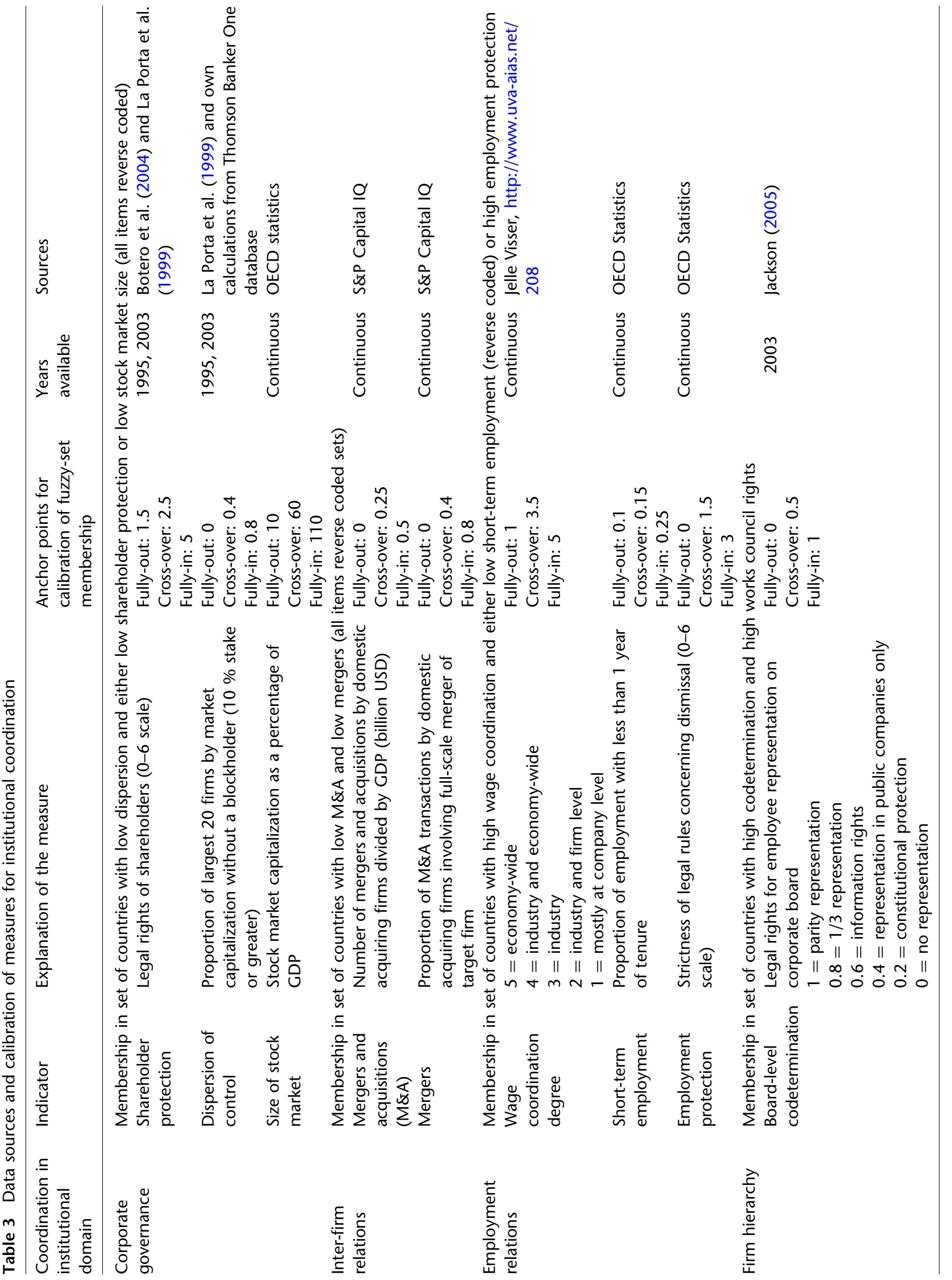




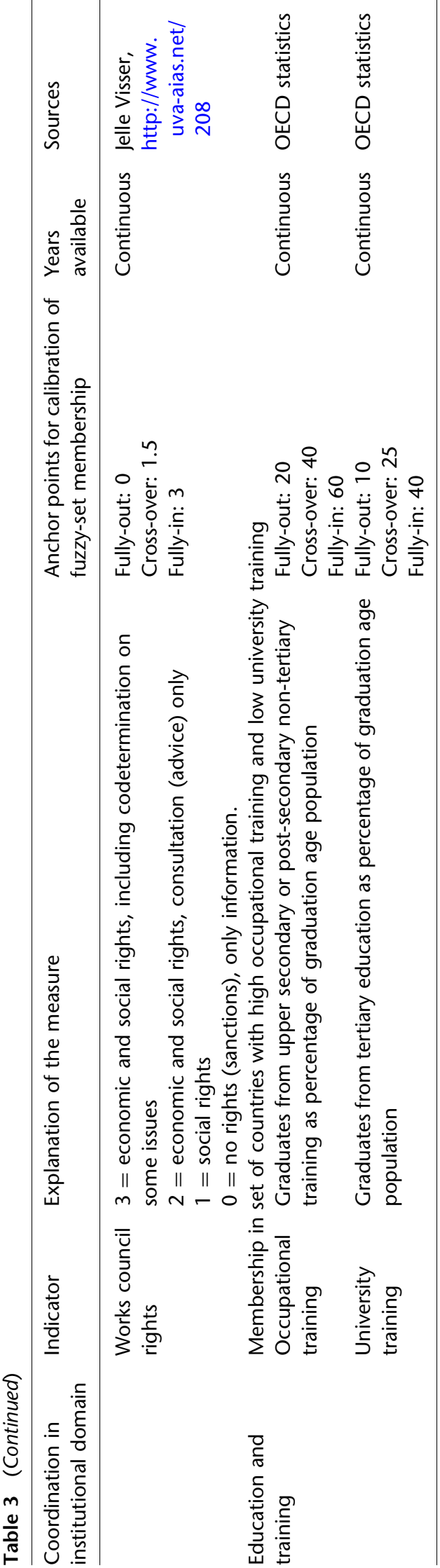

innovations in particular industries relative to the mean level of radical innovations for each country. We considered citations in the bottom $25 \%$ and top $75 \%$ to be fully out or fully in the set of highly cited patents, whereas zero difference with the country mean would indicate a crossover point between comparative disadvantage or advantage for that industry relative to overall country performance. While this indicators looks at relative advantages of countries across industries, the results of our fsQCA analysis proved identical to an alternative calibration that directly compared the proportion of radical patents in each industry between different countries. In order to further check the robustness of this radicality measure, we applied the same procedure to measures of radicality based on generality or originality dimensions, and then constructed a higherorder set membership scores for radical innovation based on citations received, originality or generality.

Finally, our outcome condition of contribution to the trade balance was calibrated based on -2 as being fully out, 2 as being fully in, and zero as the cross-over point. Substantively, the contribution to the trade balance score of zero offers an intuitive crossover point, since this score represents no comparative advantage or disadvantage. The anchors for no and full membership are slightly greater than two standard deviations around the crossover point. This calibration correlates highly with the rank ordering of cases, and our results proved robust to alternative anchor points. ${ }^{4}$

\section{Data Analysis}

Our analysis used fsQCA to evaluate which of the $2^{6}$ possible combinations of causal conditions (where 6 represents 5 institutional conditions plus industry-level radicality) are sufficient conditions for the outcome of high contribution to the trade balance. In evaluating the data, our solutions needed to meet several thresholds (e.g., Fiss, 2011; Judge et al., 2015; Ragin, 2008). First, we accepted only solutions with a consistency score (a measure of reliability) that showed a statistically significant level above the common benchmark of 0.80 . Second, we excluded any solutions that were simultaneously consistent with the negation of the outcome. This problem of simultaneous subsets is possible where set membership in causal conditions is very low (Schneider \& Wagemann, 2012). Third, valid solutions required a threshold of 40 
Table 4 Set membership of countries in highly coordinated institutions, 1995-2003 average

\begin{tabular}{|c|c|c|c|c|c|}
\hline & $\begin{array}{l}\text { Corporate } \\
\text { Governance }\end{array}$ & $\begin{array}{l}\text { Inter-firm } \\
\text { Relations }\end{array}$ & $\begin{array}{l}\text { Firm } \\
\text { Hierarchy }\end{array}$ & $\begin{array}{l}\text { Employment } \\
\text { Relations }\end{array}$ & $\begin{array}{l}\text { Occupational } \\
\text { Training }\end{array}$ \\
\hline Austria & 0.90 & 0.63 & 0.95 & 0.74 & 0.90 \\
\hline Australia & 0.08 & 0.17 & 0.00 & 0.33 & 0.07 \\
\hline Belgium & 0.83 & 0.45 & 0.40 & 0.86 & 0.70 \\
\hline Canada & 0.10 & 0.19 & 0.00 & 0.22 & 0.05 \\
\hline Denmark & 0.61 & 0.36 & 0.73 & 0.30 & 0.17 \\
\hline Finland & 0.40 & 0.14 & 0.73 & 0.36 & 0.19 \\
\hline France & 0.40 & 0.40 & 0.60 & 0.38 & 0.38 \\
\hline Germany & 0.36 & 0.63 & 0.95 & 0.74 & 0.83 \\
\hline Greece & 0.85 & 0.75 & 0.05 & 0.83 & 0.16 \\
\hline Ireland & 0.29 & 0.06 & 0.05 & 0.41 & 0.04 \\
\hline Italy & 0.79 & 0.49 & 0.20 & 0.86 & 0.72 \\
\hline Japan & 0.11 & 0.61 & 0.00 & 0.70 & 0.11 \\
\hline Netherlands & 0.40 & 0.28 & 0.80 & 0.70 & 0.26 \\
\hline Norway & 0.79 & 0.44 & 0.73 & 0.59 & 0.13 \\
\hline New Zealand & 0.61 & 0.35 & 0.00 & 0.22 & 0.04 \\
\hline Portugal & 0.77 & 0.83 & 0.05 & 0.57 & 0.02 \\
\hline South Korea & 0.40 & 0.71 & 0.00 & 0.22 & 0.28 \\
\hline Spain & 0.45 & 0.63 & 0.20 & 0.17 & 0.13 \\
\hline Sweden & 0.30 & 0.22 & 0.73 & 0.60 & 0.41 \\
\hline Switzerland & 0.18 & 0.28 & 0.27 & 0.57 & 0.74 \\
\hline UK & 0.01 & 0.07 & 0.00 & 0.22 & 0.05 \\
\hline USA & 0.01 & 0.07 & 0.00 & 0.19 & 0.05 \\
\hline
\end{tabular}

Note: Set membership scores $0.5-1$ indicate medium to full membership in the category of high coordinated, whereas scores 0 to 0.5 indicate zero to medium membership (shaded cells) in the set of coordinated countries and thereby displaying liberal institutional features.

cases. Standard applications of fsQCA are usually small-N, with a common threshold of two cases (e.g., Fiss, 2011). Since we are using fsQCA in a large $\mathrm{N}$ setting, we chose a stricter threshold on the consideration that any valid solution would have to contain observations from about two years or two industries per country. Solutions with fewer cases than 40 were treated as being inconsistent. We confirmed robustness of this choice by increasing and decreasing the threshold. Finally, our analysis does not contain any strictly directional hypotheses linking institutional factors to comparative advantage outcomes, since our hypotheses suggest that both liberal and coordinated institutions may lead to comparative advantage under certain conditions. Thus while we identify the "core conditions" as provided by the parsimonious solutions (cf. Fiss, 2011), we do not postulate any "easy counterfactuals" to be used as simplifying assumptions and interpret the results of the fsQCA complex solutions only.

\section{RESULTS}

Table 5 shows the results of our analysis. It suggests three pathways to high contribution to the trade balance, with a coverage of 0.482 (i.e., they jointly explain $48.2 \%$ of membership in our dataset). Consistency levels (similar to statistical significance) are all high throughout at levels of 0.914 and higher, which is considerably better than the commonly used minimum threshold of 0.800 .

Solution 1 combines low radicality with high coordination across all institutional spheres. This corresponds to incremental innovation producing a comparative advantage in CMEs and thus offers partial support of H1. Austria follows this CME pattern, achieving comparative advantage across a 
Table 5 Sufficient conditions for high revealed comparative advantage

\begin{tabular}{|c|c|c|c|}
\hline & Solution 1 & Solution 2 & Solution 3 \\
\hline Radicality & $\otimes$ & $\bullet$ & $\bullet$ \\
\hline Corporate governance coordination & & $\otimes$ & $\otimes$ \\
\hline Employment relations coordination & $\bullet$ & $\bullet$ & $\bullet$ \\
\hline Education and skills coordination & • & $\otimes$ & $\bullet$ \\
\hline Firm hierarchy coordination & 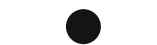 & $\otimes$ & $\bullet$ \\
\hline Interfirm coordination & & & $\bullet$ \\
\hline Raw coverage & 0.170 & 0.376 & 0.177 \\
\hline Unique coverage & 0.057 & 0.248 & 0.026 \\
\hline Consistency & 0.939 & 0.928 & 0.949 \\
\hline Total coverage, all solutions & 0.482 & & \\
\hline Solution consistency, all solutions & 0.914 & & \\
\hline
\end{tabular}

Note: $\bullet=$ presence of condition, $\otimes=$ absence of condition, blank $=$ absence or presence does not matter; large symbols show core conditions (parsimonious solution).

range of industries such as office equipment, aircraft, and metals. Notably, Austrian industries experienced only incremental forms of innovation, while radical innovation was essentially absent. However, this result only gives partial support for $\mathrm{H} 1$, as the second pattern predicted by $\mathrm{H} 1$, high radicality with low coordination across all institutional spheres, is absent from the set of solutions.

Solution 2 combines radicality with low coordination in all institutional spheres except employment relations. Interestingly, inter-firm relations are irrelevant to this solution and may be either liberal or coordinated. This result is consistent with $\mathrm{H} 2$ and describes Japan (e.g., motor vehicles, aircraft), Switzerland during the late 1990s (e.g., chemicals), and Ireland (e.g., chemicals, medical equipment sectors) as key cases. While Japan is often seen as an exemplar of CMEs (e.g., Witt, 2006; Yamamura \& Streeck, 2003), albeit with unusual characteristics, our measures present a different picture. Japan is characterized by a fairly liberal set of institutions - education is focused more on university graduates with general skills, employee voice in firm hierarchies is not strongly rooted in law, and after substantial changes to corporate governance during the 1990s, shareholder rights and patterns of corporate ownership became fairly liberal. Nonetheless, Japanese firms sustained "microcorporatist" arrangements within the domain of employment relations based on strong employment protection and low labor turnover. Unlike more pure LME economies, stable employment is core to the success of Japanese manufacturing, such as Toyota.

Solution 3 combines high radicality with high coordination in all institutional spheres except for corporate governance, which is consistent with H3. Germany falls into this category and achieved high comparative advantage in motor vehicles, chemicals, pharmaceuticals, machinery and metal products. During the 1990s, Germany underwent substantial liberalization of its corporate governance arrangements, despite relative continuity of its coordinated employment relations and strong occupational training institutions (Jackson, 2003). During this period, changes in corporate governance exerted substantial pressure on organized labor to cooperate in firm restructuring and support changes in business models. This, we argue, ultimately served here as a type of "beneficial constraint" on coordinated patterns of business organization in the sense of balancing the logic of coordination with a stronger market-orientation. The importance of this "opposing" institutional logic is clear if we compare Germany to its neighboring Austria, which represents a pure CME-type of economy and excelled only in incrementally innovative industries with a notable absence of success with radical innovation.

We conducted a number of robustness tests. First, we used a more stringent calibration of the dependent variable measuring contribution to the trade balance by changing the anchor points for low and high contribution to the trade balance from -2 to -4 and +2 to +4 , respectively. This produced precisely the same three solutions as our main model. Coverage dropped minimally from 0.485 to 0.482 , while consistency improved from 0.914 to 0.933 . Second, we used the Balassa index instead of contribution to the trade balance as a dependent variable. This produced a single solution that is identical with Solution 3 in our main model (describing the case of Germany). Coverage was 0.194 , consistency, 0.925 . This lends support to $\mathrm{H} 3$ only. At the same time, given the issues with construct validity of the Balassa index as noted earlier, we are not very confident that this support, or the lack 
Table 6 Sufficient conditions for low revealed comparative advantage

\begin{tabular}{|c|c|c|c|c|}
\hline & Solution 1 & Solution 2 & Solution 3 & Solution 4 \\
\hline Radicality & $\otimes$ & $\otimes$ & $\bullet$ & $\otimes$ \\
\hline Corporate governance coordination & $\otimes$ & & & \\
\hline Employment relations coordination & & & & $\otimes$ \\
\hline Education and skills coordination & $\otimes$ & $\otimes$ & $\otimes$ & $\otimes$ \\
\hline Firm hierarchy coordination & $\otimes$ & $\bullet$ & $\otimes$ & $\otimes$ \\
\hline Interfirm coordination & $\otimes$ & $\otimes$ & $\bullet$ & \\
\hline Raw coverage & 0.345 & 0.199 & 0.283 & 0.408 \\
\hline Unique coverage & 0.008 & 0.048 & 0.120 & 0.042 \\
\hline Consistency & 0.880 & 0.921 & 0.914 & 0.854 \\
\hline Total coverage, all solutions & 0.595 & & & \\
\hline Solution consistency, all solutions & 0.844 & & & \\
\hline
\end{tabular}

Note: $\bullet=$ presence of condition, $\otimes=$ absence of condition, blank = absence or presence does not matter; large symbols show core conditions (parsimonious solution).

of support of the other hypotheses, is particularly meaningful. Third, we used a more comprehensive measure of radicality. The three measures of radicality discussed earlier - number of patents received, originality, and generality - represent functional substitutes in that all three have been described as potential expressions of radicality in innovation. Following Ragin's (2008) approach for functional substitutes, we combined all three variables using an OR operator that is, the highest value of any of these three variables became the radicality measure for each given data point. This model produced two solutions, which are equivalent to Solutions 2 and 3 in our main model. Joint coverage was 0.362 , and all consistency scores were above 0.908 . This provides additional support of $\mathrm{H} 2$ and $\mathrm{H} 3$, but no support of $\mathrm{H} 1$.

Overall, these results offer strong support of $\mathrm{H3}$ and, given our doubts about the Balassa index, H2. Partial support of $\mathrm{H} 1$ is confined to our main model and thus seems more tentative.

Unlike in correlational methods, solutions consistent with high and low contribution to the trade balance are not necessarily symmetrical in fsQCA (Schneider \& Wagemann, 2012). The additional results in Table 6 are helpful in interpreting our findings for the main model. Solutions 1 and 4 show that low contribution to the trade balance is consistent with countries with liberal institutions across 3 or 4 institutional domains and the absence of radical innovation. This finding is essentially a mirror of Solution 1 in Table 5, but shows that countries approximating LMEtype configurations do not achieve comparative advantage in industries with low radicality. Solution 2 describes several Nordic cases, such as Norway, Denmark and Finland that have coordinated corporate governance and firm hierarchies with liberal inter-firm relations and education. This configuration is consistently associated with low contribution to trade balance in industries if radical innovation is absent. Unlike pure CMEs, coordination is absent in certain domains such as employment relations, being rather focused on a more liberal flexicurity employment model. At the same time, coordinated corporate governance does not act as a beneficial constraint visà-vis market-oriented employment patterns, since concentrated share ownership is not sufficient in itself to induce investments in firm-specific skills and capacities needed for incremental innovation. In addition, Solution 3 shows a configuration for low contribution to the trade balance describing Greece and Portugal, as well as some years for New Zealand and Spain. This configuration shows that radicality is associated with poor performance where coordinated institutions for corporate governance and inter-firm relations are mixed with liberal patterns for firm hierarchies and education. Despite the mix of coordinated and liberal elements, the configuration lacks complementarities based on beneficial constraints. Again, coordinated corporate governance, such as highly concentrated ownership patterns, or weak M\&A activity in inter-firm relations do not act as a constraining counterbalance to liberal market-oriented patterns of education and employment. As such, these particular "mixed market economies" fail to obtain comparative advantage in radical industries (Hancké, Rhodes, \& Thatcher, 2007).

\section{DISCUSSION}

In this article we used fsQCA to examine how country-level institutional configurations relate to institutional comparative advantage across 
different industrial sectors characterized by either more radical or incremental patterns of innovation. Our main finding is that radical innovation consistently leads to high comparative advantage in countries with institutions that combine specific liberal and coordinated elements: Radical innovation leads to comparative advantage in economies with predominantly liberal institutions but coordinated employment relations and, conversely, in economies with predominantly coordinated institutions but liberal corporate governance. We interpret these "mixed" or hybrid combinations of liberal and coordinated institutions as having complementarities derived from beneficial constraints, whereby an institutional logic of either market or coordinated exchange is counter-balanced by an opposing institutional logic.

One implication of our results relates to the validity of the Varieties of Capitalism hypothesis (H1). While we find some evidence that CMEs have an institutional comparative advantage in industries with incremental innovation, the data show no indication that LMEs have an institutional comparative advantage in industries with radical innovation. Additional regression analysis, reported in the Appendix, also shows no clear support of H1. This lack of strong and consistent support based on state-of-the-art measures and methodology suggests that the Varieties of Capitalism framework needs substantial reinterpretation and further theoretical development.

At the same time, our results are broadly consistent with earlier studies linking performance in certain sectors with institutional configurations that go beyond the LME and CME dichotomy. For example, Boyer (2004) explored what institutional configurations are consistent with a technology-led growth regime based on information and communications technology. He identified three different configurations, none consistent with Hall and Soskice's (2001) notion of complementarities through coherence. Similarly, Schneider et al. (2010) linked hybrid economies with mixed institutional logics to strong export performance in high technology industries. Our article lends additional support to the argument that certain types of hybrids may be more successful than the pure types envisioned by Hall and Soskice (2001).

The key contribution here is to go beyond these previous studies by offering an ex ante prediction of the kinds of results we expect to see, drawing on the concept of beneficial constraints. This approach, which builds on Streeck (1997), allowed us to theorize how complementarities may alternatively be based on the combination of conflicting institutional logics. Here complementarities may result from opposing logics, in which liberal and coordinated institutions compensate for one another. Specifically, coordinated employment relations institutions may constrain the influence of liberal markets, thereby enabling firms to make and protect investments in core human resources. Meanwhile, in highly coordinated economies, liberal corporate governance may act as an external monitor that constrains the behavior of company stakeholders, but in ways that also enable more rapid and successful adaptation to radical innovation. Nonetheless, our analysis shows clearly that not all hybrid combinations of markets and coordination achieve these sorts of beneficial constraints. In mixed market economies, such as Greece of Portugal, neither does liberal corporate governance act as an external monitor for highly coordinated patterns of organization, nor does coordinated employment relations serve as a constraint of liberal market organization. Of course, our analysis leaves a number of cases unexplained, which suggests a research agenda to better map and test hybrid institutional logics based on beneficial constraints.

Complementarities based on opposing principles of social organization have a further and potentially wide-ranging implication: that complementarities should be understood as political projects, not equilibrium outcomes. For example, as Germany faced economic turmoil in the early 1990s, the political process of liberalization triggered a process where more coordinated employment relations were defended and adapted to new constraints of more liberal corporate governance. While this institutional dynamism may have energized the economy, one consequence has been increasing inequality and the political temptation to liberalize institutions further, which may undo the success (Streeck, 2009). Thus new hybrid configurations of institutions are no more stable equilibria than more coherent configurations; rather, institutions change dynamically all the time. The Celtic Tiger or Danish flexicurity are other good examples. These "success models" of one era eventually run their course, often because the winners and losers of changing institutional arrangements push for further processes of institutional change (Thelen, 2014). As countries travel past certain windows, they may gain comparative advantages, but these combinations of institutional 
arrangements may eventually exhaust themselves as other countries and innovation patterns change in unison (Boyer, 2004). Here a key finding of our study is that the competitive advantage of Germany was based not simply on its presumed character as an ideal-typical CME country; rather, it did better than pure CMEs like Austria by incorporating hybrid institutional logics. Similarly, we can go beyond other country stereotypes in the literature to compare other unexpected pairs, such as Ireland and Japan. Rather than being opposed as LME and CME types, we can further investigate the parallel ways in which these countries combine liberal institutions with high coordination in employment relations.

Our findings also add to the still relatively sparse literature linking the comparative capitalism literature to economic outcomes. There is little doubt that there are institutional differences, but the "so what?" - whether and where these variations matter - has been much less explored. Our study finds that institutional comparative advantage may indeed exist, though possibly not in the manner previously envisaged. Importantly, this suggests adopting research designs that allow for causal complexity and equifinality, whereby different institutional structures can lead to similar outcomes. The original Varieties of Capitalism approach (Hall \& Soskice, 2001) suggested equifinality between CMEs and LMEs with respect to overall economic wealth, but posited a more simple relationship between LMEs and the ability to leverage radical innovation. By contrast, our results suggest that at least two different institutional configurations are associated with comparative advantage in the presence of radical innovation. Furthermore, these configurations are dramatically different: either all elements but corporate governance are coordinated, or all but employment relations are liberal.

Our conceptualization of complementarities based on opposing logics and the empirical results on equifinality challenge some existing conceptualizations of institutional differences in International Business. For example, recent works have already noted that the impact of distances may not be symmetric or even indicative of difficulty operating abroad (Cuervo-Cazurra \& Genc, 2012). In this context, we hope that our approach can help provide a basis for future empirical work on the economic impact of Varieties of Capitalism in particular and of institutional differences in International Business more generally. Our study shows the potential benefits of using fsQCA to elucidate the conjunctural effects of different combinations of institutional indicators (Ragin, 2008). While previous studies have applied fsQCA methods to the Varieties of Capitalism literature, our results are broadly consistent with past results that have linked more complex institutional configurations that go beyond the simple LME and CME types with stronger economic growth or export performance (Kogut \& Ragin, 2006; Schneider et al., 2010). The multidimensionality evident in our analysis calls for international business scholars to pay greater attention to differences in kinds of institutions and their combination, rather than conceptualizing of institutions as one-dimensional differences in degrees, as done widely in literatures on institutional distance, institutional development or even Varieties of Capitalism (Jackson \& Deeg, 2008). It also suggests that benefits usually associated with social structures may be contingent on the presence of other, supportive institutional structures. For instance, while our analysis generally supports the widely accepted notion that interorganizational networks may produce beneficial outcomes (e.g., Dyer \& Singh, 1998; Sako, 1992), Solution 3 in Table 6 suggests that in some configurations, they may be associated with weak performance.

Our findings may further have important implications for understanding the location choices of multinational enterprises (MNEs) seeking to avoid home country disadvantages, project competitive advantages related to their home country, or exploit complementary resources and knowledge related to host country institutional environments (cf. Jackson \& Deeg, 2008; Singh, 2007; Witt \& Lewin, 2007). The literature has previously identified host country institutions as sources of locational advantages (Dunning and Lundan 2008), which suggests the possibility of institutional arbitrage (Jackson \& Deeg, 2008; Witt \& Lewin, 2007): Firms may move their operations, in part or in whole, to institutional contexts that better support these operations. The Varieties of Capitalism literature would have suggested that firms should locate activities involving radical innovations in LMEs such as the United States. Our results suggest a different picture: Production involving radical innovation seems to thrive in economies pairing either liberal corporate governance with coordination in the other spheres of the political economy, or coordinated employment relations with formally liberal institutions in other areas. These patterns are 
far more complex than connections between institutions and locational choices of MNEs previously explored in the literature, such as political risk or corruption (Henisz, 2002; Rodriguez, Uhlenbruck, $\&$ Eden, 2005). At the same time, it is possible that experience and evolutionary processes have shaped MNE investment patterns accordingly. To the extent this is the case, one would expect that MNEs relying more on radical innovations locate relatively more of their activities in these economies. One would also expect that the performance of MNEs relying more on radical innovations should correspond to the extent to which they locate their operations in economies with suitable institutional configurations. Exploring these hypotheses would seem to be a fruitful avenue for future IB research.

\section{Limitations}

Though our empirical findings are robust to a large number of alternative specifications, they have important methodological limitations.

First, our results may be limited to the specific time frame and country sample. Our study is based on a 9-year window from 1995 through 2003, for reasons of data availability as explained earlier. This period covers the time period for which the Varieties of Capitalism approach claimed validity (cf. Hall \& Gingerich, 2009) and constitutes a strong test of the original hypothesis. Nonetheless, as newer data become available, future studies might examine whether the hypothesized comparative advantages manifest themselves post-2003. For example, the full effects of the Internet revolution, shifts in biotechnology or expansion of global value chains may be clearer over a longer time span. Moreover, while our sample covers all countries discussed by Hall and Soskice, and while Varieties of Capitalism theory focuses on advanced industrialized economies, it is possible that a larger range of countries might lead to more comprehensive insights.

A second limitation concerns the construct validity of the coordination and radicality measures. Concerning the former, Hall and Soskice discussed the notion of transferable versus relational assets across the five institutional domains of corporate governance and finance, employment relations, education, managerial hierarchies within firms, and inter-firm relations. However, little consensus exists about which institutional indicators should be used to best capture "coordination" in each domain. While we believe that our variables maximized construct validity to the extent possible, better measures may become available.
In terms of radicality, we faced the same problem that has plagued all prior attempts at exploring the hypothesis: how to measure it. Our operationalization follows procedures used and accepted by the specialist literature on R\&D. However, patent data and even patent citations have well-known limitations. Not all innovations can be patented (e.g., new software), and firms do not necessarily patent their innovations for cost or strategic reasons (Archibugi \& Planta, 1996). Moreover, radical innovation may also be associated with process innovations driven by changes in organization for which new technology is a necessary but not a sufficient condition. Our results analyze the impact of radicality across a wide range of industries, but different dynamics may occur and different institutional features may be salient within specific industries. As such, our article does not exhaust this agenda.

The notion of radicality can also be questioned at a deeper level. It remains unclear whether radical innovation is properly understood at the level of patents, meaning proprietary inventions, or whether it entails shifts in broader technological paradigms independent of particular inventions or applications. For example, major shifts in information technology are not centered on single radical inventions, but may imply a radical shift in business models or the locus of competitive advantage. These broader phenomena, like the information technology revolution, may give firms in LMEs new opportunities to leverage institutions for fast entry and exit from lines of business, or to use external labor markets to retool their human capital and organizational capabilities. But we cannot discount the idea that firms in CMEs will leverage their institutions to make incremental innovations around this same context, whereby information technologies are integrated successfully into established product lines in ways leading to quality or process improvements. Put differently, comparative advantage may be reconceived as being less centered on advantages related to a fixed boundary of an industry or technology. Rather, innovation may be refracted through the lens of institutions in ways that are leveraged for more radical or incremental shifts in business strategy and organization. Here multinational firms with capabilities for institutional bricolage may have distinctive advantages. Indeed, research on Central and Eastern Europe has started to find competitive advantage in high-tech industries based on strong FDI with complex institutional hybrids that involve combinations of 
liberal elements with either strong employee participation or longer-term employment relations (Allen \& Aldred, 2011). As such, we think the agenda of understanding how coordinated relations act as beneficial constraints on markets has a long future ahead.

\section{ACKNOWLEDGMENTS}

We thank Jaeyong Song for his constructive editorial guidance and the three anonymous reviewers for their insightful feedback. We are further grateful for comments and input received from Robert Boyer, Daniel W. Gingerich, Bronwyn H. Hall, Sebastian Koos, and Gerald A. McDermott. Rashid Ansari at INSEAD and Sören Salzwedel at FU Berlin provided valuable research assistance, and we thank the INSEAD libraries for their support. Michael Witt also thanks the Humboldt Foundation for funding two 3-month research stays in Berlin to undertake this project.

\section{REFERENCES}

Akkermans, D., Castaldi, C., \& Los, B. 2009. Do 'liberal market economies' really innovate more radically than 'coordinated market economies'? Hall and Soskice reconsidered. Research Policy, 38(1): 181-191.

Allen, M. 2004. The varieties of capitalism paradigm: Not enough variety? Socio-Economic Review, 2(1): 87-108.

Allen, M. M. C., \& Aldred, M. L. 2009. Varieties of capitalism, varieties of innovation? A comparison of old and new EU member states. Journal of Contemporary European Research, 5(4): 581-596.

Allen, M. M. C., \& Aldred, M. L. 2011. Varieties of capitalism, governance, and high-tech export performancea fuzzy-set analysis of the new EU member states. Employee Relations, 33(4): 334-355.

Amable, B. 2003. The diversity of modern capitalism. Oxford: Oxford University Press.

Aoki, M. 2010. Corporations in evolving diversity: Cognition, governance, and institutions. Oxford: Oxford University Press.

Aoki, M., \& Jackson, G. 2008. Understanding an emergent diversity of corporate governance and organizational architecture: An essentiality-based analysis. Industrial and Corporate Change, 17(1): 1-27.

Archibugi, D., \& Planta, M. 1996. Measuring technological change through patents and innovation surveys. Technovation, 16(9): 451-519.

Balassa, B. 1965. Trade liberalisation and "revealed" comparative advantage. The Manchester School, 33(2): 99-123.

Bassanini, A., \& Ernst, E. 2002. Labour market regulation, industrial relations and technological regimes: A tale of comparative advantage. Industrial and Corporate Change, 11(3): 391-426.

Bell, G., Filatotchev, I., \& Aguilera, R. 2013. Corporate governance and investors' perceptions of foreign ipo value: An institutional perspective. Academy of Management Journal, 57(1): 301-320.

Block, F. L., \& Somers, M. R. 2014. The power of market fundamentalism: Karl Polanyi's critique. Cambridge, MA: Harvard University Press.

\section{NOTES}

1Porter's (1990) work on the competiveness of nations has been an important influence in the development of these new approaches. We exclude it from the discussion because Porter's focus is on competitiveness and thus on absolute advantage rather than on comparative advantage.

${ }^{2}$ On the notion of institutions as resources more generally, see also Hall and Thelen (2009) and Jackson and Deeg (2008).

${ }^{3}$ This original index has also important empirical limitations, please refer to the Appendix.

${ }^{4}$ Generally, raising thresholds for full membership produced very similar results, whereas lowering thresholds to just one standard deviation produced fewer consistent results, as the resultant calibration no longer distinguishes between cases of high and very high contributions to the trade balance.

Blyth, M. 2003. Same as it never was: Temporality and typology in the varieties of capitalism. Comparative European Politics, 1(2): 215-225.

Bohle, D., \& Greskovits, B. 2009. Varieties of capitalism and capitalism "tout court". European Journal of Sociology, 50(3): 355-386.

Botero, J. C., Djankov, S., La Porta, R., Lopez-de-Silanes, F., \& Shleifer, A. 2004. The regulation of labor. Quarterly Journal of Economics, 19(4): 1339-1382.

Boyer, R. 2004. New growth regimes, but still institutional diversity. Socio-Economic Review, 2(1): 1-32.

Brewster, C., Wood, G., \& Brookes, M. 2006. Varieties of capitalism and varieties of firm. In P. James, \& G. Wood (Eds), Institutions, production, and working life. Oxford: Oxford University Press.

Campbell, J. L. 2011. The US financial crisis: Lessons for theories of institutional complementarity. Socio-Economic Review, 9(2): 211-234.

Carney, M., Gedajlovic, E., \& Yang, X. 2009. Varieties of Asian capitalism: Toward an institutional theory of Asian enterprise. Asia Pacific Journal of Management, 26(3): 361-380.

Crilly, D. 2011. Predicting stakeholder orientation in the multinational enterprise: A mid-range theory. Journal of International Business Studies, 42(5): 694-717.

Crouch, C. 2005. Capitalist diversity and change. Recombinant governance and institutional entrepreneurs. Oxford: Oxford University Press.

Crouch, C., \& Streeck, W. 1997. Political economy of modern capitalism: Mapping convergence and diversity. London: Sage.

Crouch, C., Streeck, W., Boyer, R., Amable, B., Hall, P. A., \& Jackson, G. 2005. Dialogue on 'institutional complementarity and political economy. Socio-Economic Review, 2(4): 359-382.

Cuervo-Cazurra, A., \& Genc, M. E. 2012. Categories of distance and international business. In G. Wood, \& M. Demirbag (Eds), Handbook of institutional approaches to international business: 219-235. Cheltenham: Edward Elgar. 
Dearsdorff, A. V. 1980. The general validity of the law of comparative advantage. Journal of Political Economy, 88(5): 941-957.

Deeg, R. 2007. Institutional complementarity and change in capitalist systems. Journal of European Public Policy, 14(4): 612-623.

Dunning, J. H., \& Lundan, S. M. 2008. Institutions and the oli paradigm of the multinational enterprise. Asia Pacific Journal of Management, 25(4): 573-593.

Dyer, J. H., \& Singh, H. 1998. The relational view: Cooperative strategy and sources of interorganizational competitive advantage. Academy of Management Review, 23(4): 660-679.

Fiss, P. C. 2011. Building better causal theories: A fuzzy set approach to typologies in organization research. Academy of Management Journal, 54(2): 393-420.

Furman, J. L., Porter, M. E., \& Stern, S. 2002. The determinants of national innovative capacity. Research Policy, 31(6): 899-933.

Gospel, H., \& Pendleton, A. 2003. Finance, corporate governance and the management of labour: A conceptual and comparative analysis. British Journal of Industrial Relations, 41(3): 557-582.

Gospel, H., \& Pendleton, A. (Eds) 2005. Corporate governance and labour management: An international comparison. Oxford: Oxford University Press.

Hall, B. H., Bessen, J., \& Thoma, G. 2011. NBER patent data project. https://sites.google.com/site/patentdataproject/Home.

Hall, P. A., \& Gingerich, D. W. 2009. Varieties of capitalism and institutional complementarities in the political economy. British Journal of Political Science, 39(3): 449-482.

Hall, B. H., Jaffe, A. B., \& Trajtenberg, M. 2001. The NBER patent citations data file: Lessons, insights and methodological tools. NBER working paper series no. 8498.

Hall, P. A., \& Soskice, D. 2001. An introduction to varieties of capitalism. In P. A. Hall, \& D. Soskice (Eds), Varieties of capitalism: The institutional foundations of comparative advantage: 1-68. Oxford: Oxford University Press.

Hall, P. A., \& Thelen, K. 2009. Institutional change in varieties of capitalism. Socio-Economic Review, 7(1): 7-34.

Hancké, B., Rhodes, M., \& Thatcher, M. (Eds) 2007. Beyond varieties of capitalism: Contradictions, complementarities \& change. Oxford: Oxford University Press.

Henisz, W. J. 2002. Politics and international investment: Measuring risks and protecting profits. London: Edward Elgar.

Herrmann, A. M., \& Peine, A. 2011. When 'national innovation system' meet 'varieties of capitalism' arguments on labour qualifications: On the skill types and scientific knowledge needed for radical and incremental product innovations. Research Policy, 40(5): 687-701.

Höpner, M. 2005. What connects industrial relations and corporate governance? Explaining institutional complementarity. Socio-Economic Review, 3(2): 331-358.

Jackson, G. 2003. Corporate governance in Germany and Japan: Liberalization pressures and responses. In K. Yamamura, \& W. Streeck (Eds), The end of diversity? Prospects for German and Japanese capitalism: 261-305. Ithaca, NY: Cornell University Press.

Jackson, G. 2005. Employee representation in the board compared: A fuzzy sets analysis of corporate governance, unionism, and political institutions. Industrielle Beziehungen, 12(3): 1-28.

Jackson, G., \& Deeg, R. 2008. Comparing capitalisms: Understanding institutional diversity and its implications for international business. Journal of International Business Studies, 39(4): 540-561.

lackson, G., \& Muellenborn, T. 2012. Understanding the role of institutions in industrial relations: Perspectives from classical sociological theory. Industrial Relations: A Journal of Economy and Society, 51(S1): 472-500.

Jackson, G., \& Ni, N. 2013. Understanding complementarities as organizational configurations using set theoretical methods. In P. C. Fiss, B. Cambré, \& A. Marx (Eds), Configurational theory and methods in organizational research: 129-158. Bingley: Emerald Group Publishing.

lackson, G., \& Petraki, A. 2010. Understanding short-termism: The role of corporate governance. Stockholm: Glasshouse Forum.

Judge, W. Q., Fainshmidt, S., \& Brown, J. L, I. I. I. 2014. Which model of capitalism best delivers both wealth and equality? Journal of International Business Studies, 45(4): 363-386.

Judge, W. Q., et al. 2015. Configurations of capacity for change in entrepreneurial threshold firms: Imprinting and strategic choice perspectives. Journal of Management Studies, 52(4): 506-530.

Kogut, B., \& Ragin, C. C. 2006. Exploring complexity when diversity is limited: Institutional complementarity in theories of rule of law and national systems revisited. European Management Review, 3(1): 44-59.

La Porta, R., Lopez-de-Silanes, F., Schleifer, A., \& Vishney, R. W. 1998. Law and finance. Journal of Political Economy, 106(6): 1113-1155.

La Porta, R., Lopez-de-Silanes, F., \& Shleifer, A. 1999. Corporate ownership around the world. Journal of Finance, 54(2): 471-517.

Longest, K. C., \& Vaisey, S. 2008. Fuzzy: A program for performing qualitative comparative analyses (QCA) in stata. Stata Journal, 8(1): 79-104.

Mahoney, J., \& Thelen, K. 2009. Explaining institutional change: Ambiguity, agency, and power. Cambridge: Cambridge University Press.

Milgrom, P. R., \& Roberts, J. 1994. Complementarities and systems: Understanding Japanese economic organization. Estudios Economicos, 9(1): 3-42.

Milgrom, P. R., \& Roberts, J. 1995. Complementarities and fit: Strategy, structure, and organizational change in manufacturing. Journal of Accounting and Economics, 19(2/3): 179-208.

Newbert, S. L. 2007. Empirical research on the resource-based view of the firm: An assessment and suggestions for future research. Strategic Management Journal, 28(2): 121-140.

Nölke, A., \& Vliegenthart, A. 2009. Enlarging the varieties of capitalism: The emergence of dependent market economies in east central Europe. World Politics, 61(4): 670-702.

OECD. 2003. Science, technology and industry scoreboard. Paris: OECD.

OECD. 2013. OECD.Stat. www.oecd-ilibrary.org/content/data/ data-00285-en.2013.

Porter, M. E. 1990. The competitive advantage of nations. New York: Free Press.

Ragin, C. C. 2000. Fuzzy-set social science. Chicago: University of Chicago Press.

Ragin, C. C. 2008. Redesigning social inquiry: Fuzzy sets and beyond. Chicago: University of Chicago Press.

Rajan, R. G., \& Zingales, L. 2000. The governance of the new enterprises. In X. Vives (Ed), Corporate governance: Theoretical \& empirical perspectives. Cambridge: Cambridge University Press.

Redding, G., \& Witt, M. A. 2007. The future of Chinese capitalism: Choices and chances. Oxford: Oxford University Press.

Redding, G., \& Witt, M. 2009. China's business system and its future trajectory. Asia Pacific Journal of Management, 26(3): 381-399.

Rodriguez, P., Uhlenbruck, L., \& Eden, L. 2005. Government corruption and the entry strategies of multinationals. Academy of Management Review, 30(2): 383-396.

Sako, M. 1992. Price, quality and trust: Inter-firm relations in britain and Japan. Cambridge: Cambridge University Press.

Schneider, M. R., \& Paunescu, M. 2012. Changing varieties of capitalism and revealed comparative advantages from 1990 to 2005: A test of the Hall and Soskice claims. Socio-Economic Review, 10(4): 731-753.

Schneider, M. R., Schulze-Bentrop, C., \& Paunescu, M. 2010. Mapping the institutional capital of high-tech firms: A fuzzy- 
set analysis of capitalism variety and export performance. Journal of International Business Studies, 41(2): 246-266.

Schneider, C. Q., \& Wagemann, C. 2012. Set-theoretic methods for the social sciences: A guide to qualitative comparative analysis. Cambridge: Cambridge University Press.

Singh, J. 2007. Asymmetry of knowledge spillovers between MNCs and host country firms. Journal of International Business Studies, 38(5): 764-786.

StataCorp. 2011. Stata statistical software: Release 12. College Station, TX: StataCorp. LP.

StataCorp. 2013. Stata statistical software: Release 13. College Station, TX: StataCorp.

Streeck, W. 1997. Beneficial constraints: On the economic limits of rational voluntarism. In J. R. Hollingsworth \& R. Boyer (Eds), Contemporary capitalism: The embeddedness of institutions: 197-219. Cambridge: Cambridge University Press.

Streeck, W. 2008. Re-forming capitalism: Institutional change in the German political economy: Institutional change in the German political economy. Oxford: Oxford University Press.

Streeck, W. 2009. Re-forming capitalism: Institutional change in the German political economy. Oxford: Oxford University Press.

Streeck, W., \& Thelen, K. (Eds) 2005. Beyond continuity: Institutional change in advanced political economies. Oxford: Oxford University Press.

Taylor, M. Z. 2004. Empirical evidence against varieties of capitalism's theory of technological innovation. International Organization, 58(Summer): 601-631.

Thelen, K. 2014. Varieties of liberalization and the new politics of social solidarity. Cambridge: Cambridge University Press.

Transparency International. 2013. Corruption perception index. http://www.transparency.org.cpi2011.

Trefler, D., \& Zhu, S. C. 2000. Beyond the algebra of explanation: Hov for the technology age. American Economic Review, 90(2): 145-149.

Visser, J. 2011. Data base on institutional characteristics of trade unions, wage setting, state intervention and social pacts, 1960-2010 (ICTWSS), Version 3.0. Amsterdam: Amsterdam

\section{APPENDIX}

As a robustness test, we used regression analysis to undertake an alternative test of H1. Regression analysis is not suitable for testing $\mathrm{H} 2$ and $\mathrm{H} 3$ because the configurational logic of these arguments would involve 6-way interaction terms. However, the argument of coherence across all 5 spheres of the political economy inherent in $\mathrm{H} 1$ makes it possible to derive a single "coordination index" to use in a 2-way interaction. While fsQCA still remains the method of choice for this kind of investigation, not least because of its ability to accommodate asymmetric solutions (see discussion in the main text), we present this additional test as a robustness check.

This Appendix reports the data, and methodology and main results. The results depend on the operationalization of the dependent variable: our preferred measure, contributions to the trade balance, does not support H1, while the Balassa index as an alternative offers inconsistent support of $\mathrm{H} 1$.
Institute for Advanced Labour Studies, University of Amsterdam.

Vitols, S. 2002. Shareholder value, management culture and production regimes in the transformation of the German chemical-pharmaceutical industry. Competition and Change, 6(3): 309-325.

Vitols, S. 2004. Negotiated shareholder value: The German version of an anglo-American practice. Competition and Change, 8(4): 1-18.

Whitley, R. 1999. Divergent capitalisms: The social structuring and change of business systems. Oxford: Oxford University Press.

Witt, M. A. 2006. Changing Japanese capitalism: Societal coordination and institutional adjustment. Cambridge: Cambridge University Press.

Witt, M. A., \& Lewin, A. Y. 2007. Outward foreign direct investment as escape response to home country institutional constraints. Journal of International Business Studies, 38(4): 579-594.

Witt, M. A., \& Redding, G. 2013. Asian business systems: Institutional comparison, clusters and implications for varieties of capitalism and business systems theory. Socio-Economic Review, 11(2): 265-300.

Witt, M. A., Kabbach de Castro, L. R., Amaeshi, K., Mahroum, S., Bohle, D., \& Saez, L. 2015. The business systems of the world's leading 61 economies: Institutional comparison, clusters, and implications for varieties of capitalism and business systems research. INSEAD working paper series, INSEAD, Fontainebleau, France.

World Bank. 2013. World development indicators. http://data. worldbank.org/data-catalog/world-development-indicators. 2011.

Yamamura, K., \& Streeck, W. (Eds) 2003. The end of diversity? Prospects for German and Japanese capitalism. Ithaca, NY: Cornell University Press.

\section{Data}

Dependent variables were the contribution to the trade balance plus the Balassa index, as discussed in the main text.

The independent variable of interest was the interaction term between radicality by number of citations received and the coordination index we introduce below. To account for possible direct effects, we also included both the radicality measure and the coordination measure in the regression.

\section{Coordination}

For each country and year, we calculated an index of overall coordination. Hall and Gingerich (2009) used confirmatory factor analysis to derive a coordination index for 20 advanced industrialized economies, with index values closer to 0 denoting higher similarity with the prototypical LME and closer to 1, with the prototypical CME. Their 
coordination index is based on three indicators of corporate governance and finance (an index of shareholder protection, dispersion of control, and the size of stock market) and three indicators of employment relations (the level of wage bargaining, the degrees of coordination in wage bargaining, and the proportion of employees with tenures of less than 1 year). This original index has a number of limitations that made it unsuitable for our study. First, it provides a point estimate for about the mid-1990s rather than a time-series over the period of our study. Second, the original factor scores calculated in Hall and Gingerich combined indicators from the late 1980s to the mid-1990s. When synchronizing the data as an annual time series for 1995-2003, we found that the indicators did not load on a common underlying factor when applying confirmatory factor analysis as used by Hall and Gingerich.

We developed an alternative specification of the coordination index using principal component analysis for the period 1995 through 2003. We drew on the 12 indicators used in our main fsQCA model as described in Table 2 of the main text. This set of indicators is more comprehensive that those used by
Hall and Gingerich but were inspired by the 5 institutional domains described in the original formulation of Varieties of Capitalism by Hall and Soskice (2001). Taking z-transformed variables to create a uniform scale, we used the principal-factor method in Stata (StataCorp, 2011) to calculate a single factor loading using squared multiple correlations to estimate the commonality of an underlying factor. The single largest factor had a factor loading of $74 \%$ and a large eigenvalue of 4.14 , suggesting a strong correlation along this single dimension of coordination. The second factor had an eigenvalue of 1.14 and explained an additional $20.7 \%$ of the variation, which suggests that some important variance is not fully captured in a single index. However, since we are interested in the extent to which countries vary on a single dimension, we did not interpret any of the other factor scores.

Figure A1 shows the factor scores for countries in our sample over time. While there is some movement of CMEs toward the LME end of the spectrum, supporting the notion that economies liberalized in the 1990s and early 2000s, we did not observe any major changes in the general ordering of positions. Table A1 lists the values.

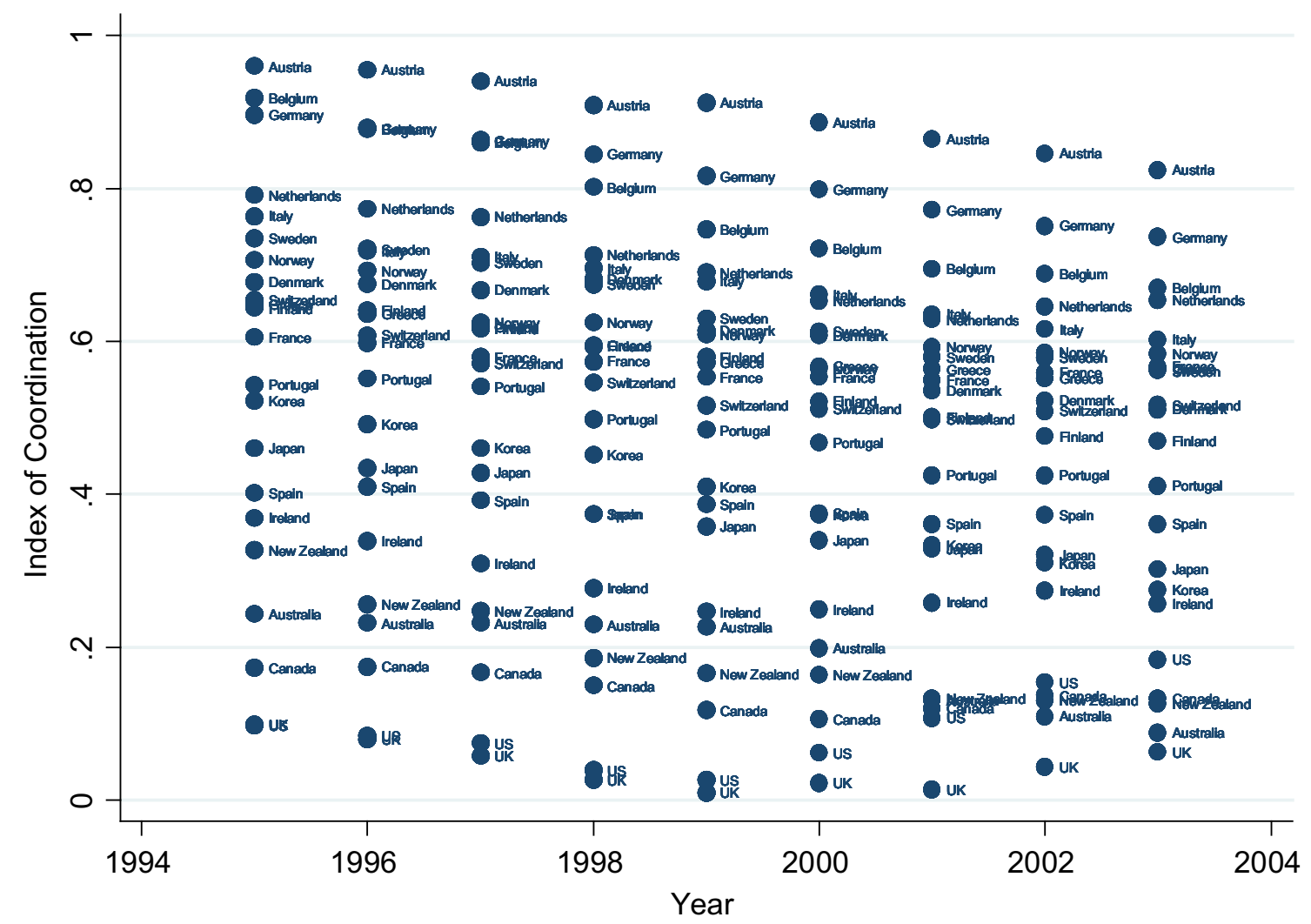

Figure A1 Coordination index, 1995-2003. 
Table A1 Coordination index for 22 OECD countries, 1995-2003

\begin{tabular}{|c|c|c|c|c|c|c|c|c|c|}
\hline Country & 1995 & 1996 & 1997 & 1998 & 1999 & 2000 & 2001 & 2002 & 2003 \\
\hline Australia & 0.24 & 0.23 & 0.23 & 0.23 & 0.23 & 0.20 & 0.13 & 0.11 & 0.09 \\
\hline Austria & 0.96 & 0.96 & 0.94 & 0.91 & 0.91 & 0.89 & 0.86 & 0.85 & 0.82 \\
\hline Belgium & 0.92 & 0.88 & 0.86 & 0.80 & 0.75 & 0.72 & 0.69 & 0.69 & 0.67 \\
\hline Canada & 0.17 & 0.17 & 0.17 & 0.15 & 0.12 & 0.11 & 0.12 & 0.14 & 0.13 \\
\hline Denmark & 0.68 & 0.67 & 0.67 & 0.68 & 0.61 & 0.61 & 0.54 & 0.52 & 0.51 \\
\hline Finland & 0.64 & 0.64 & 0.62 & 0.59 & 0.58 & 0.52 & 0.50 & 0.48 & 0.47 \\
\hline France & 0.60 & 0.60 & 0.58 & 0.57 & 0.55 & 0.55 & 0.55 & 0.56 & 0.57 \\
\hline Germany & 0.90 & 0.88 & 0.86 & 0.84 & 0.82 & 0.80 & 0.77 & 0.75 & 0.74 \\
\hline Greece & 0.65 & 0.64 & 0.62 & 0.59 & 0.57 & 0.57 & 0.56 & 0.55 & 0.56 \\
\hline Ireland & 0.37 & 0.34 & 0.31 & 0.28 & 0.25 & 0.25 & 0.26 & 0.27 & 0.26 \\
\hline Italy & 0.76 & 0.72 & 0.71 & 0.70 & 0.68 & 0.66 & 0.64 & 0.62 & 0.60 \\
\hline Japan & 0.46 & 0.43 & 0.43 & 0.37 & 0.36 & 0.34 & 0.33 & 0.32 & 0.30 \\
\hline Netherlands & 0.79 & 0.77 & 0.76 & 0.71 & 0.69 & 0.65 & 0.63 & 0.65 & 0.65 \\
\hline New Zealand & 0.33 & 0.26 & 0.25 & 0.19 & 0.17 & 0.16 & 0.13 & 0.13 & 0.13 \\
\hline Norway & 0.71 & 0.69 & 0.62 & 0.62 & 0.61 & 0.56 & 0.59 & 0.59 & 0.58 \\
\hline Portugal & 0.54 & 0.55 & 0.54 & 0.50 & 0.48 & 0.47 & 0.43 & 0.43 & 0.41 \\
\hline South Korea & 0.52 & 0.49 & 0.46 & 0.45 & 0.41 & 0.37 & 0.33 & 0.31 & 0.27 \\
\hline Spain & 0.40 & 0.41 & 0.39 & 0.37 & 0.39 & 0.37 & 0.36 & 0.37 & 0.36 \\
\hline Sweden & 0.73 & 0.72 & 0.70 & 0.67 & 0.63 & 0.61 & 0.58 & 0.58 & 0.56 \\
\hline Switzerland & 0.65 & 0.61 & 0.57 & 0.55 & 0.52 & 0.51 & 0.50 & 0.51 & 0.52 \\
\hline UK & 0.10 & 0.08 & 0.06 & 0.03 & 0.01 & 0.02 & 0.01 & 0.04 & 0.06 \\
\hline USA & 0.10 & 0.08 & 0.07 & 0.04 & 0.03 & 0.06 & 0.11 & 0.15 & 0.18 \\
\hline
\end{tabular}

Note: Higher values indicate higher levels of CME-style coordination.

We used this variable in its interaction with radicality (which then provided the independent variable of interest for testing $\mathrm{H} 1$ ) and its direct effect in the regression to control for the possibility that coordination in itself affects revealed comparative advantages without interacting with radicality.

Control variables included the following:

Number of patents This industry-level control variable is the natural logarithm of the number of patents in the given country, industry, and year (OECD, 2013). It controlled for the possibility that greater contributions to the trade balance in a given industry may be the result of higher levels of innovation in general, as opposed to radical innovation.

Corruption levels and regulatory quality These country-level control variables are the corruption perception index, obtained from Transparency International (2013), and the regulatory quality measures from the World Bank Development Indicators database (2013). They controlled for the possibility that institutional shortcomings may prevent patent owners from making full use of their patents, which could reduce contributions to the trade balance an economy can derive from radical innovations.
EU, NAFTA These country-level control variables are dummy variables coded 1 if the respective country was a member of the EU or NAFTA and 0 otherwise. It controlled for the possibility that membership in these free trade areas may have an impact on the structure of trade of a country and thus on the structure of contributions to the trade balance.

GDP per capita This country-level control variable is the natural logarithm of per capita GDP at purchasing power parity and constant year 2000 US dollars (OECD, 2013). It controlled for possible structural effects in contributions to the trade balance based on higher levels of economic development. For instance, it is possible that higher GDP levels may be associated with greater comparative advantage in higher technology industries.

GERD per GDP This country-level control variable is the ratio of Gross Expenses on R\&D over GDP (OECD, 2013). It controlled for possible effects that higher levels of spending on R\&D in an economy may have on contributions to the trade balance.

We further included dummies for all years in the sample. Table A2 shows descriptive statistics for all variables. 


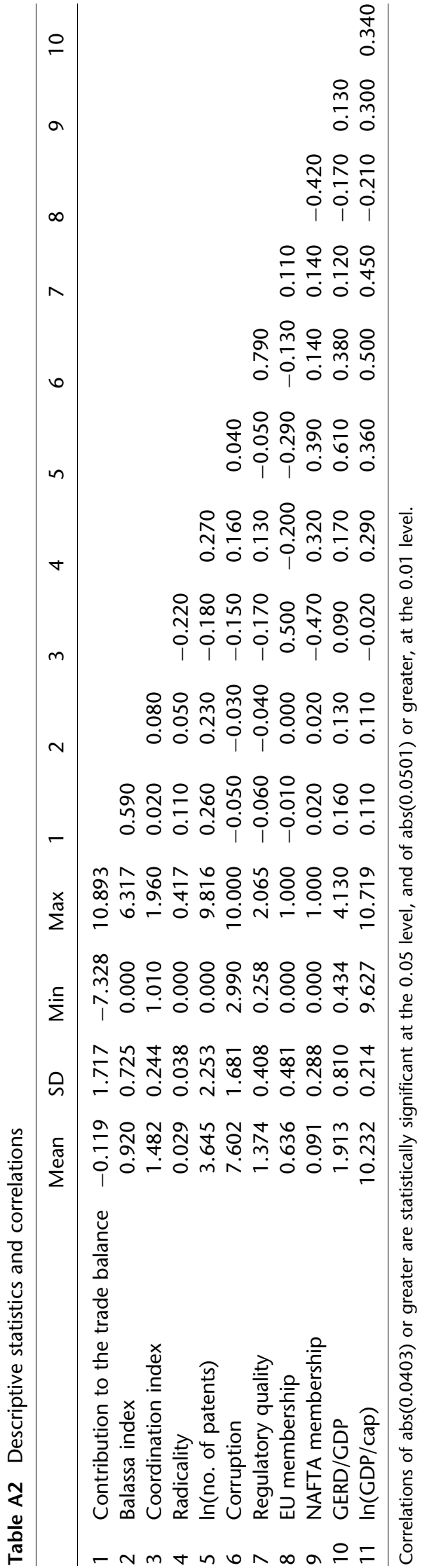

\section{Model Specification}

We used hierarchical linear modeling (HLM), as implemented in the "mixed" command in Stata 13.1 (StataCorp, 2013). This choice was conditioned by the presence of multiple violations of the assumption that data are independent and identically distributed. Specifically, we expected clustering effects at two levels, country and industry. In line with the Varieties of Capitalism approach, we assumed that country-level characteristics supersede industry-level characteristics and consequently specified a three-level HLM model that nested observations first in industries and then in countries. We further specified robust standard errors with correction for $\mathrm{AR}(1)$ autoregressive effects. Robustness tests with $\operatorname{AR}(2)$ and $\operatorname{AR}(3)$ specification yielded qualitatively identical results.

\section{Results}

Models (1) through (3) in Table A3 show the buildup to our main model (3), which is a three-level HLM specification regressing the contribution to the trade balance variable on the interaction of coordination and radicality expressed in citations received.

The coefficient estimate for the interaction effect is negative, as expected, and statistically significant. However, further analysis revealed that the result in model (3) is dependent on the presence of two specific sets of data points: the chemical and pharmaceutical industries in Ireland, both of which have received unusually large levels of inward foreign direct investment for production for export. Dropping these two industries for Ireland resulted in insignificant coefficient estimates, as model (4) indicates. No other countries or industries showed similar impact. The problem persisted when using OLS with clustered standard errors, either by industry or country, or when changing the lag to 2 or 3 years, as well as when using the alternative measures of radicality discussed in the main text. We conclude that the results of model (3) are contingent on 18 influential data points representing said two industries in Ireland and thus not generally supported.

Model 5 shows the results for the Balassa index as the dependent variable. The coefficient estimate for the interaction effect is negative, as expected, and statistically significant. Unlike in model 3 , this result is not contingent on the presence of Irish outlier data points, and it is robust to inverting the 
Table A3 Regression results

\begin{tabular}{|c|c|c|c|c|c|}
\hline & $\begin{array}{l}\text { (1) } \\
\text { Contribution to } \\
\text { trade balance }\end{array}$ & $\begin{array}{l}\text { (2) } \\
\text { Contribution to } \\
\text { trade balance }\end{array}$ & $\begin{array}{l}\text { (3) } \\
\text { Contribution to } \\
\text { trade balance }\end{array}$ & $\begin{array}{l}\text { (4) } \\
\text { Contribution to trade } \\
\text { balance, no outliers }\end{array}$ & $\begin{array}{c}(5) \\
\text { Balassa }\end{array}$ \\
\hline \multicolumn{6}{|l|}{ Controls } \\
\hline $\ln$ (number of & $0.0807^{* * *}$ & $0.0804^{* * *}$ & $0.0800^{* \star \star}$ & $0.0775^{\star \star *}$ & 0.000702 \\
\hline patents) & $(0.0184)$ & $(0.0184)$ & $(0.0184)$ & $(0.0170)$ & $(0.00614)$ \\
\hline \multirow[t]{2}{*}{ Corruption levels } & -0.00944 & -0.0100 & -0.00840 & -0.00844 & 0.000640 \\
\hline & $(0.0189)$ & $(0.0189)$ & $(0.0189)$ & $(0.0174)$ & $(0.00647)$ \\
\hline \multirow[t]{2}{*}{ Regulatory quality } & -0.0438 & -0.0436 & -0.0330 & -0.0118 & 0.00733 \\
\hline & $(0.0748)$ & $(0.0752)$ & $(0.0753)$ & $(0.0690)$ & $(0.0263)$ \\
\hline \multirow[t]{2}{*}{ EU membership } & 0.103 & 0.103 & 0.0954 & 0.00765 & -0.00803 \\
\hline & $(0.216)$ & $(0.223)$ & $(0.222)$ & $(0.215)$ & $(0.0923)$ \\
\hline \multirow[t]{2}{*}{ NAFTA membership } & -0.275 & -0.283 & -0.327 & -0.169 & 0.0623 \\
\hline & $(0.366)$ & $(0.373)$ & $(0.373)$ & $(0.361)$ & $(0.155)$ \\
\hline \multirow[t]{2}{*}{ GERD/GDP } & 0.0296 & 0.0298 & 0.0308 & 0.0587 & 0.0217 \\
\hline & $(0.0593)$ & $(0.0593)$ & $(0.0593)$ & $(0.0549)$ & $(0.0211)$ \\
\hline \multirow[t]{2}{*}{$\ln (G D P / c a p)$} & $0.926^{* *}$ & $0.904^{* *}$ & $0.871^{* \star}$ & 0.451 & 0.213 \\
\hline & $(0.284)$ & $(0.286)$ & $(0.286)$ & $(0.268)$ & $(0.113)$ \\
\hline Year dummies & Yes & Yes & Yes & Yes & Yes \\
\hline \multirow{2}{*}{ Coordination index } & & 0.00524 & 0.109 & 0.101 & $0.242^{\star}$ \\
\hline & & $(0.281)$ & $(0.284)$ & $(0.265)$ & $(0.107)$ \\
\hline \multirow[t]{2}{*}{ Radicality } & & 0.399 & $5.482^{* *}$ & 0.587 & $1.603^{*}$ \\
\hline & & $(0.289)$ & $(2.073)$ & (1.930) & $(0.699)$ \\
\hline \multirow[t]{2}{*}{ Coordination $\times$ radicality } & & & $-3.432^{*}$ & -0.482 & $-1.076^{*}$ \\
\hline & & & $(1.386)$ & $(1.285)$ & $(0.468)$ \\
\hline \multirow[t]{2}{*}{ Constant } & $-9.760 * * *$ & $-9.552^{* * *}$ & $-9.394^{\star \star}$ & -5.164 & -1.675 \\
\hline & $(2.859)$ & $(2.865)$ & $(2.862)$ & $(2.692)$ & $(1.136)$ \\
\hline$N$ & 2772 & 2772 & 2772 & 2754 & 2772 \\
\hline$A I C$ & 3108.5 & 3110.6 & 3106.5 & 2627.6 & -2821.2 \\
\hline$B I C$ & 3227.0 & 3241.0 & 3242.8 & 2763.8 & -2684.9 \\
\hline Log likelihood & -1534.2 & -1533.3 & -1530.2 & -1290.8 & 1433.6 \\
\hline$\chi^{2}$ & 40.98 & 42.90 & 49.13 & 34.53 & 17.48 \\
\hline
\end{tabular}

Note: Standard errors in parentheses.

${ }^{*} p<0.05,{ }^{* *} p<0.01,{ }^{* * *} p<0.001$.

nesting of the HLM specification. Graphing the interaction showed that the higher Balassa scores of CME countries decline with increasing radicality, whereas the lower Balassa scores of LME countries increase with radicality. However, the estimates of Balassa at high levels of radicality have wide confidence intervals, so that we cannot say with confidence that LMEs outperform CMEs at high levels - a conservative statement would be to say the disadvantages of LMEs are diminished. Looking at other model specifications, the interaction term became statistically insignificant if OLS with clustered standard errors by industry or by country was used. Using originality as a measure of radicality resulted in a statistically significant result with the wrong (positive) sign, while the use of generality produced no statistically significant result. Taking all this together, we see at best tentative support of $\mathrm{H} 1$ in these results even if the Balassa index represented a meaningful measure of revealed comparative advantage, which we doubt.

\section{ABOUT THE AUTHORS}

Michael A. Witt is Affiliate Professor of Strategy and International Business at INSEAD. He earned his PhD at Harvard University and explores national institutions and their impact on managerial and organizational outcomes. His papers have appeared in journals such as JIBS, SMJ, JMS, BEQ, $J B E, M O R$, and SER. He has published four scholarly books, including The Oxford Handbook of Asian Business Systems (with Gordon Redding).

Gregory Jackson is Professor of Management at the Freie Universität Berlin and Einstein Research 
Fellow at the Berlin Social Science Center. He earned his PhD in Sociology at Columbia University, and his research interests include corporate governance, corporate social responsibility and irresponsibility and comparative management.

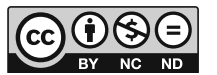

This work is licensed under a Creative cial-NoDerivs 3.0 Unported License. The images or

Michael A. Witt and Gregory Jackson have contributed equally to this article. The authors have a policy of alternating author order of joint papers.

Accepted by Jaeyong Song, Area Editor, 18 April 2016. This article has been with the authors for three revisions. other third party material in this article are included in the article's Creative Commons license, unless indicated otherwise in the credit line; if the mons license, users will need to obtain permission from the license holder to reproduce the material. To view a copy of this license, visit http:// creativecommons.org/licenses/by-nc-nd/3.0/ material is not included under the Creative Com-

epted by taeyong Song, Area Editor, 18 April 2016. This article has been with the authors for three revisions. 